\author{
FERNANDO GUZMÁN* \\ LORENZO BERG** \\ Giovanna CAPitelli ${ }^{* * *}$ \\ Stefano CRACOLici ${ }^{* * * *}$ \\ Elisabetta Pallottino ${ }^{* * * * *}$ \\ KATHERINE VyHMEISTER ${ }^{* * * * * *}$
}

\title{
ROMA Y LA RENOVACIÓN DE LA IMAGEN Y EL ESPACIO SACRO \\ EN CHILE DURANTE EL SIGLO XIX ${ }^{1}$
}

\begin{abstract}
RESUMEN
A partir de la cuarta década del siglo XIX la élite intelectual chilena comenzó a referirse a la necesidad de renovar el espacio y la imagen sagrada. La construcción de la nueva nación requería una iglesia moderna que cultivara en los fieles una piedad ilustrada, propósito que requería la supresión del espacio y la imagen barroca, cuyas formas promovían una religiosidad que se consideraba inapropiada. Esta misma élite instaló el prestigio de Roma, de sus iglesias, altares e imágenes, como un faro al cual debían remitirse los arquitectos, escultores y pintores que colaborarían en esta regeneración del espacio y la imagen sagrada. La actividad en Chile de arquitectos y escultores formados en Roma, así como la llegada de obras ejecutadas en los talleres de la Ciudad Eterna, fueron factores decisivos para hacer realidad este proyecto de renovación. Sin embargo, la documentación local registra una resistencia pasiva de la población a estos cambios concebidos por la élite. Los casos de las iglesias de la Recoleta Dominica, del archipiélago de Chiloé, de San Ignacio, de Andacollo y de la capilla del Seminario de Santiago, que se revisarán en el presente texto, permiten conocer las diversas formas de transferencia y apropiación de estos nuevos modelos.
\end{abstract}

* Doctor en Historia del Arte, Universidad de Sevilla. Profesor titular de la Universidad Adolfo Ibáñez. Investigador del Centro de Estudios del Patrimonio (Chile). Correo electrónico: fernando.guzman@uai.cl

** Doctor en Arquitectura, Universidad Politécnica de Madrid. Profesor asociado del Instituto de Historia y Patrimonio, Facultad de Arquitectura y Urbanismo, Universidad de Chile. Correo electrónico: loberg@u.uchile.cl

*** Dottore di ricerca in Storia e Conservazione dell'Oggetto d'Arte e d'Architettura, Università degli Studi Roma Tre. Profesora Asociada del Dipartimento di Studi Umanistici, Università degli Studi Roma Tre (Italia).Correo electrónico: giovanna.capitelli@uniroma3.it

${ }^{* * * * *}$ Ph.D. in Italian Studies, University of Toronto. Professor / Director of the Zurbarán Centre for Spanish and Latin American Art, School of Modern Languages and Cultures, Durham University (United State). email: stefano.cracolici@durham.ac.uk

****** Architetto, Sapienza Università di Roma. Professore Ordinario, Dipartimento di Architettura dell' Università degli Studi Roma Tre (Italia). E-mail: elisabetta.pallottino@uniroma3.it

******* Ph.D.(c) in Architectural History, The University of Edinburgh. Investigadora del Centro de Estudios del Patrimonio, Universidad Adolfo Ibáñez (Chile). Correo electrónico: kvyhmeister@uai.cl

${ }^{1}$ Artículo elaborado en el marco del proyecto de cooperación internacional Chile-Italia, ANID ITAL170007 y Ministero degli Affari Esteri e della Cooperazione Internazionale CH18M001. 
Palabras claves: Chile, Roma, Santiago, Chiloé, Andacollo, siglo XIX, espacio sagrado, imagen sagrada, San Ignacio, Recoleta Dominica.

\begin{abstract}
Since the 1840s the Chilean intellectual elite began to think about the renovation of sacred spaces and images. The building of the new nation required a modern Church that encouraged an 'enlightened piety' among worshipers, for which it was necessary to suppress the Baroque space and images whose forms promoted a religiosity considered to be inappropriate. The same elite placed Rome in a position of prestige, its churches, altarpieces, and images, as the guide that architects, sculptors, and painters, who played a key role in the renovation of sacred spaces and images, had to follow. The presence in Chile of architects and sculptors trained in Rome, as well as the commission of artworks from the Eternal City ateliers, were critical to materialize the renovation project. Nevertheless, contemporary documents show people's passive resistance against the changes conceived by the elite. The cases of the churches of the Recoleta Dominica, the Chiloé archipielago, Andacollo, San Ignacio, and the Seminar chapel of Santiago analyzed in this study allow us to understand how the transference and appropriation of these new models were articulated.
\end{abstract}

Keywords: Chile, Rome, Santiago, Chiloé, Andacollo, nineteenth century, Sacred Space, Sacred Images, San Ignacio, Recoleta Dominica.

Recibido: Octubre 2020.

Aceptado: Marzo 2021.

\title{
INTRODUCCIÓN
}

Hasta hace unos pocos años la historiografía chilena no había prestado atención a las transformaciones que se produjeron en el ámbito de la imagen y el espacio sacro durante la segunda mitad del siglo XIX, así como tampoco había atendido al papel que pintores, escultores y arquitectos formados en Roma tuvieron en este proceso ${ }^{2}$. La falta de interés en el arte y la arquitectura religiosa del periodo, así como la escasa conciencia de los vínculos culturales con Roma, entre otros factores, impedían que la investiga-

\footnotetext{
${ }^{2}$ Eugenio Pereira Salas, Estudios sobre la historia del arte en Chile republicano, Santiago, Ediciones de la Universidad de Chile / Fundación Andes, 1992; Milan Ivelic y Gaspar Galaz, La pintura en Chile desde la colonia hasta 1981, Valparaíso, Ediciones Universidad Católica de Valparaíso, 1981; Víctor Carvacho Herrera, Historia de la escultura en Chile, Santiago, Editorial Andrés Bello, 1983; Isabel Cruz, Arte en Chile. Historia de la pintura y escultura desde la Colonia al siglo XX, Santiago, Editorial Antártica, 1984; Eugenio Pereira Salas, La arquitectura chilena en el siglo XIX, Santiago, Ediciones de los Anales de la Universidad de Chile, 1958; Enrique Solanich Sotomayor, Escultura en Chile. Otra mirada para su estudio, Santiago, Editorial Amigos del Arte, 2000; Liisa Flora Voionmaa Tanner, Escultura pública. Del monumento conmemorativo a la escultura pública, Santiago 1792-2004, Santiago, Ocho Libros Editores, 2004; Antonio Romera, Historia de la pintura chilena, Santiago, Editorial Zig-Zag, 1960; Osvaldo Cáceres, La arquitectura de Chile independiente, Concepción, Ediciones Universidad del Bío-Bío, 2007.
} 
ción mostrara avances significativos ${ }^{3}$. Las referencias a la actividad en Chile del pintor Alessandro Ciccarelli ${ }^{4}$, napolitano formado en Roma, así como las menciones al trabajo del arquitecto Eusebio Chelli ${ }^{5}$, por ejemplo, no se lograban articular en un relato más amplio. De este modo, un vasto patrimonio, formado por pinturas, esculturas, piezas de orfebrería, así como numerosas iglesias, se estudiaban en forma aislada, sin atender a su carácter de manifestaciones de un fenómeno mayor.

Durante la segunda mitad del siglo XIX, la arquitectura y el arte religioso en Chile experimentaron cambios de particular relevancia. A partir de la cuarta década de la centuria, algunos miembros de la élite local comenzaron a manifestar su rechazo por la apariencia de las iglesias coloniales, con sus retablos dorados y su ornamentación barroca ${ }^{6}$. Las soluciones espaciales de las antiguas iglesias, así como las imágenes que en ellas se albergaban, fueron vistas como un freno para la formación del sentido artístico de la población y el desarrollo de una piedad ilustrada ${ }^{7}$. En consecuencia, fue tomando forma la

\footnotetext{
${ }^{3}$ Giovanna Capitelli, "Los 'pintores de Pio IX' en Santiago de Chile: los misterios del rosario para la iglesia de la Recoleta Dominica (1870)”, en Fernando Guzmán y Juan Manuel Martínez (eds.), Arte americano e independencia: Nuevas iconografias, Santiago, Museo Histórico Nacional / Universidad Adolfo Ibáñez / CREA, 2010, pp. 45-57.

${ }^{4}$ Eusebio Chelli (Carrara 1830-1890). Véanse: VV.AA., Allgemeines Künstlerlexikon, Die Bildenden Künstler aller Zeiten und Völker, München und Leipzig, K.G. Saur, Verlag, 1998, vol. 18, p. 381; Ramón Gutiérrez, "Arquitectos italianos en Sudamérica, siglos XIX y XX”, en Ricerche di storia dell'arte, n. ${ }^{\circ} 63$, Roma, 1997, pp. 53-72.

${ }^{5}$ Alessandro Ciccarelli (Nápoles 1810-1879 Santiago). Véase: Romera, op. cit., pp. 50-52; Isabel Cruz, “"La Atenas del Pacífico'. Alejandro Cicarelli y el proyecto civilizador de las Bellas Artes en Chile republicano", en Tiempos de América, n. ${ }^{11}$, Castellón de la Plana, 2004, pp. 91-104; Josefina de la Maza, "Duelo de pinceles: Ernesto Charton y Alejandro Ciccarelli. Pintura y enseñanza en el siglo XIX chileno", en Fernando Guzmán y Juan Manuel Martínez (eds.), Vínculos artísticos entre Italia y América. Silencio historiográfico, Santiago, Museo Histórico Nacional / Universidad Adolfo Ibáñez / Centro de Restauración / CREA, 2012, pp. 219-228; Pedro Zamorano, "El discurso de Alejandro Ciccarelli con motivo de la fundación de la Academia de Pintura: claves de un modelo estético de raigambre clásica", en Guzmán y Martínez, Vinculos artísticos..., op. cit., pp. 197-205.

${ }^{6}$ Mario Góngora, “Aspectos de la Ilustración Católica en el pensamiento y la vida eclesiástica chilena (1770-1814)”, en Mario Góngora (ed.), Estudios de historia de las ideas y de historia social, Valparaíso, Ediciones Universitarias de Valparaíso, 1980, p. 129; Sol Serrano, ¿Qué hacer con Dios en la República? Politica y secularización en Chile (1845-1885), Santiago, Fondo de Cultura Económica, 2008, p. 39; Sol Serrano, "Espacio público y espacio religioso en Chile republicano", en Teología y Vida, vol. XLIV, Santiago, 2003, pp. 346-355; Sol Serrano, "La privatización del catolicismo barroco: Y la publicidad del catolicismo moderno. Una mirada a la secularización en el caso chileno", en Atenea, n. ${ }^{\circ} 484$, Concepción, 2001, pp. 43-62; Sol Serrano, "La privatización del culto y la piedad católicas", en Rafael Sagredo y Cristián Gazmuri (eds.), Historia de la vida privada en Chile. Tomo II: El Chile moderno 1840 a 1925, Santiago, TaurusAguilar, 2006, pp. 139-155; Fernando Guzmán, Representaciones del paraíso, retablos en Chile siglos XVIII y XIX, Santiago, Editorial Universitaria, 2009, pp. 97-118; Fernando Guzmán, "L'Arte di Roma nel Cile del XIX secolo. Un elemento delle strategie di rappresentazione dell'identità nazionale. Il caso degli altari", in Giovanna Capitelli, Stefano Grandesso e Carla Mazzarelli (eds.), Roma fuori di Roma. L'esportazione dell'arte moderna da Pio VII all'Unità (1775-1870), Roma, Campisano Editore, 2012, pp. 419-430.

${ }^{7}$ Si bien la práctica de una piedad ilustrada comenzó a establecerse ya en el siglo XVIII en Hispanoamérica a partir de las ideas reformistas ilustradas promovidas por instituciones oficiales españolas, no fue sino hasta entrado el siglo XIX que estas ideas permearon el discurso artístico en Chile. Según Carlos Martínez, a pesar de las críticas de la Ilustración hacia el ámbito religioso, casi la totalidad de los pensadores españoles del setecientos mantuvo su fidelidad a la Iglesia católica, forjándose así una 'ilustración cristiana': "En este sentido, la conciencia de que el reformismo de las Luces no minaba los cimientos de la religión,
} 
convicción de que era necesario promover la reforma de los espacios sacros. Los nuevos edificios e imágenes religiosas, junto con colaborar de modo decisivo en la educación artística de la población, promoverían una vida religiosa moderna ${ }^{8}$, libre de los excesos del periodo colonial ${ }^{9}$. En este contexto, los modelos arquitectónicos y artísticos romanos fueron cruciales. El trabajo en Chile de arquitectos italianos que habían trabajado en Roma, el significativo flujo de arte religioso desde la Ciudad Eterna a diversas ciudades chilenas, así como la formación en Roma de algunos artistas nacionales ${ }^{10}$, generó una estrecha relación entre muchas iglesias locales y las tipologías de espacio sagrado que se desarrollaron y se promovieron durante el siglo XIX en Roma ${ }^{11}$, de modo especial con las que habían contribuido a difundir en Europa, entre las décadas 1820 y 1840, un decidido revival paleocristiano o, más bien, un renacimiento cristiano clásico, como la basílica de San Pablo Extramuros que estaba siendo reconstruida ${ }^{12}$.

La reconstrucción de la basílica de San Pablo Extramuros, después del terrible incendio de 1823, representó un momento crucial en el debate acerca del cuidado de los monumentos en Roma. La Academia de San Lucas, portavoz de la comunidad artística, discutió qué solución adoptar para restaurar la imagen de este importante monumento de la catolicidad. En último término, fue decisión directa del pontífice León XII, contenida en la encíclica Ad Plurimas de 1825, reconstruir la basílica "dove era e como era". Si bien el primer proyecto se debe al arquitecto Pasquale Belli, se puede sin duda afirmar que el aspecto general de la basílica se debe al arquitecto Luigi Poletti. El sitio de cons-

sino que contribuía a reforzarlos mediante su depuración, es una constante entre los escritores avanzados de la época...”. Carlos Martínez Shaw, Historia de España. El Siglo de las Luces. Las bases intelectuales del reformismo, Madrid, Historia 16, 1996, pp. 69-70.

${ }^{8}$ Se entiende aquí como moderno todo aquello que se opone a la herencia cultural del periodo colonial.

${ }^{9}$ José Victorino Lastarria, Investigaciones sobre la influencia social de la conquista i del sistema colonial de los españoles en Chile, Santiago, Imprenta del Siglo, 1844, p. 113; José Ignacio Víctor Eyzaguirre, Los intereses católicos en América, París, Librería de Garnier Hermanos, 1859, vol. II, p. 74; José Ignacio Víctor Eyzaguirre, Instrucciones para los sacerdotes, Roma, Imprenta Políglota, 1875; Góngora, op. cit., p. 129.

${ }^{10}$ El caso más relevante es el de Miguel Campos, pensionado chileno en la Academia de San Lucas. Véase El Ferrocarril, n. ${ }^{\circ}$ 4922, Santiago, 26 de agosto de 1871.

${ }^{11}$ Capitelli, "Los 'pintores de Pio IX'...”, op. cit.; Giovanna Capitelli, Mecenatismo pontificio e borbónico alla vigilia dell'Unità, Roma, Viviani Editore, 2011, pp. 158-179; Guzmán, "L'Arte di Roma...”, op. cit.; Stefano Cracolici, "Sotto il segno del Martirio: Roma e l'eredità artistica della fede”, en Guzmán y Martínez, Vinculos artísticos..., op. cit., pp. 43-54.

${ }^{12}$ Luigi Canina fue uno de los protagonistas más activos en esta dirección, a partir de la década del cuarenta, con la publicación de las dos ediciones de "Ricerche sull'architettura più proprie dei tempi cristiani...", Roma 1843 y 1846. Acerca de la reconstrucción de la basílica véase de modo especial los siguientes trabajos de Elisabetta Pallottino: "La nuova architettura paleocristiana nella ricostruzione della basilica di S. Paolo fuori le mura a Roma (1823-1847)", in Ricerche di Storia dell'arte, n. ${ }^{\circ}$ 56, Roma, 1995, pp. 30-59; "Architettura e archeologia intorno alle basiliche di Roma e alla ricostruzione di S. Paolo f.l.m.", in A. L. Bonella, A. Pompeo e M. I. Venzo (eds.), Roma fra la Restaurazione e l'elezione di Pio IX. Amministrazione, Economia. Società e Cultura, Roma, Friburgo / Vienna, Herder, 1997, pp. 329-347; y "La ricostruzione della basilica di San Paolo fuori le mura (1823-1854)", in Stefano Susinno, Sandra Pinto, Liliana Barroero e Fernando Mazzocca (eds.), Maestà di Roma: Da Napoleone All'unità d'Italia: Universale ed Eterna, Capitale delle Arti, Milano, Electa, 2003, pp. 484-489 y 490-501. Véase también: Michael Groblewski, Thron und Altar: Der Wiederaufbau der Basilika St. Paul vor den Mauern (1823-1854), Friburgo, Basilea / Vienna, Herder, 2001. Se encuentra en curso de redacción una nueva contribución acerca de la historia de la reconstrucción de la basílica en el contexto europeo, escrito por Richard Wittman. 
trucción de esta enorme fábrica se convirtió en una verdadera escuela para los trabajadores, para los artistas, para los decoradores, quienes participaron en forma activa en la creación de su nuevo aspecto ${ }^{13}$.

A este traspaso de modelos artísticos y arquitectónicos se debe agregar la relevancia de Roma como proveedora de prestigio, de modo tal que la presencia de ciertos materiales, la participación puntual de un pintor o escultor, o la intervención parcial de un arquitecto romano en una obra edilicia, era capaz de revestir el total de una obra, a pesar de su posible distancia con los modelos artísticos o arquitectónicos, de ese carácter romano que muchos buscaron imprimir en el espacio y la imagen sagrada. La atracción de Roma es inherente a su primacía exportadora, no tanto como un modelo de referencia, sino como un lugar de encuentro cosmopolita donde, de modo colectivo, se daba forma a una idea de prestigio tanto artístico como devocional ${ }^{14}$.

El caso chileno, aunque rico en su especificidad, se inscribe en ese fenómeno más amplio de exportación artística y cultural en el que se ha acumulado una bibliografía considerable: comenzando con la exposición de 2003 sobre la Maestà di Roma. Universale ed Eterna. Capitale delle Arti, planificada y diseñada por Stefano Susinno, que terminó con una pionera reflexión acerca de "Roma fuori di Roma"; asunto que se profundizó luego en un volumen a varias voces lanzado en 2012 (como resultado de una intensa red de intercambios entre colegas italianos, alemanes, franceses, británicos, suizos, rusos, españoles y latinoamericanos), así como en dos series de conferencias del ciclo de las Jornadas de Historia del Arte organizadas en Chile en 2010 y $2012^{15}$. La relevancia global del siglo XIX romano fue investigada a través de estudios de caso elocuentes en el volumen de Giovanna Capitelli sobre el Mecenatismo pontificio e borbonico alla vigilia dell'unità (2011), y en una exposición reciente en el Museo Nacional de San Carlos, en la Ciudad de México, dedicada a intercambios artísticos entre Roma y México $(2018)^{16}$. Es, en cambio, de reciente creación un proyecto internacional de investigación sobre la correspondencia de los artistas como instrumento útil para conocer

${ }^{13}$ Nicola Camerlenghi, St. Paul's Outside the Walls: A Roman Basilica from Antiquity to the Modern Era, Cambridge, Cambridge University Press, 2018; Marina Docci, San Paolo fuori le mura: dalle origini alla basilica delle origini, Roma, Gangemi, 2006; Elisabetta Pallottino, "La ricostruzione della basilica di San Paolo fuori le Mura”, in Roma Moderna e Contemporanea, vol. 20, n. ${ }^{2}$, Roma, 2012, pp. 681-701. En este último texto se encuentra un registro de la rica bibliografía precedente.

${ }^{14}$ Para la idea de "zona de prestigio" véase: Randall Collins, "Civilizations as Zones of Prestige and Social Contact”, in International Sociology, vol. 16, No. 3, London, 2001, pp. 421-437. Por su aplicación al contexto romano del siglo XIX véase: Stefano Cracolici, “Nuestra patria es tu patria también': Un martire romano per i Gesuiti di Santiago”, en Giovanna Capitelli, Macarena Carroza, Stefano Cracolici, Fernando Guzmán y Juan Manuel Martínez, Arte en la iglesia de San Ignacio, Santiago, RIL Editores, 2017, pp. 147-170, en particular pp. 150-151.

${ }^{15}$ Giovanna Capitelli y Stefano Grandesso, "Roma fuori di Roma”, in Susinno, Pinto, Barroero e Mazzocca, op. cit., pp. 589-600. Alessandra Imbellone, "L'arte moderna esce da Roma: regesto delle licenze d'esportazione dal 1775 al 1870", in Capitelli, Grandesso y Mazzarelli, op. cit., pp. 626-726.

${ }^{16}$ Capitelli, Mecenatismo pontificio..., op. cit.; Giovanna Capitelli y Stefano Cracolici, “Apostar por Roma: arte en México en el siglo de la Independencia”, en Giovanna Capitelli y Stefano Cracolici (eds.), Roma en México/México en Roma: las academias de arte entre Europa y el Nuevo Mundo, 1843-1867, Roma, 2018, pp. 19-56 (catálogo de la exposición realizada en el Museo Nacional de San Carlos, México, 6 diciembre del 2018 al 24 de abril del 2019). 
las redes globales de transmisión a través de las que se difunde el saber artístico romano a lo largo del siglo XIX ${ }^{17}$. Es esta versión más móvil de la geografía, así como de la historiografía artística, la que pretende recoger la presente contribución.

El objetivo de la investigación que ahora se presenta ha sido examinar la adopción de los modelos arquitectónicos y artísticos romanos como una de las vías elegidas para superar la pesada herencia de los retablos dorados y las imágenes policromadas, configurando así un espacio y una imagen sagrada coherente con una depuración de las prácticas coloniales de piedad. Al mismo tiempo, se ha prestado atención a las manifestaciones de acogida y resistencia a estos procesos de transformación. La primera parte del texto se hace cargo de identificar y analizar los factores más relevantes que configuraron este anhelo reformador, en el que los modelos romanos representaron un papel decisivo. La segunda parte del artículo presenta el estudio de cinco casos emblemáticos, entre los que se incluyeron tres iglesias santiaguinas -la Recoleta Dominica, San Ignacio y la capilla del Seminario- junto a ejemplos de edificios levantados en contextos periféricos: la basílica de Andacollo y las iglesias decimonónicas del archipiélago de Chiloé. Este repertorio permite reconocer las dinámicas de apropiación de los nuevos modelos en contextos diversos, así como identificar los cambios que se producen en un arco temporal que comienza en 1854, con la colocación de la primera piedra de la Recoleta Dominica y culmina en 1898, con la consagración de la capilla del Seminario.

\section{PURIFICAR EL ARTE Y LA PIEDAD}

La historiografía ha construido una imagen de la actividad artística de la primera mitad del siglo XIX en Chile en la que se muestra una profunda renovación ${ }^{18}$. Algunos factores, como la creciente demanda por retratos, la erección de los primeros monumentos públicos republicanos y la presencia de pintores europeos que cultivan el paisaje o las temáticas costumbristas, parecen dominar la escena ${ }^{19}$. Se trata de un relato que habla de hechos bien documentados, pero que, al omitir otros fenómenos de la misma relevancia, termina entregando una imagen distorsionada. Hasta la década del cuarenta del siglo XIX muchos artistas locales, junto a otros de origen quiteño, seguían produciendo pintura y escultura religiosa de acuerdo con los patrones técnicos y estilísticos del periodo colonial ${ }^{20}$.

\footnotetext{
${ }^{17}$ Serenella Rolfi Ožvald, Susanne Adina, Carla Mazzarelli e Giovanna Capitelli (coords.), Lettere di artista. Corrispondenze tra Roma e l'Europa dall'età dei Lumi alla Restaurazione, dossier en Ricerche di Storia dell'arte, n. ${ }^{\circ}$ 125, Roma, Carocci editore, 2018; Serenella Rolfi Ožvald e Carla Mazzarelli (eds.), Il carteggio d'artista: fonti, questioni, ricerche tra XVII e XIX secolo, Milano, Silvana Editoriale, 2019.

${ }^{18}$ Sintomáticas son algunas estrategias discursivas, como la de Milan Ivelic y Gaspar Galaz quienes titulan el primer capítulo relativo al arte del siglo XIX como "El despertar artístico" (Ivelic y Galaz, op. cit., p. 39). Antonio Romera, por su parte, titula "Los precursores y sus seguidores" al capítulo dedicado a las primeras décadas de la centuria (Romera, op. cit., p. 16). 'Despertar' y 'precursores' son palabras que remiten a un periodo anterior en el que el arte habría estado aletargado y a un presente en el que se forja una nueva tradición.

${ }^{19}$ Cruz, Arte en Chile..., op. cit., pp. 113-308.

${ }^{20}$ Alexandra Kennedy, "Arte y artistas quiteños de exportación”, en Alexandra Kennedy, Arte de la Real Audiencia de Quito, siglo XVII-XIX, Madrid, Editorial Nerea, 2002, pp. 185-203; Alexandra Kennedy, "Circuitos artísticos interregionales: de Quito a Chile. Siglos XVIII y XIX”, en Historia, vol. 31, Santiago, 1998,
} 
La mayoría de las iglesias aún albergaban impresionantes retablos barrocos, dorados y ornamentados con profusión, cuyas hornacinas contenían esculturas de madera policromada y pinturas de los siglos XVII y XVIII ${ }^{21}$. Hasta mediados del siglo XIX las obras de nuevo cuño no eran más que excepciones y el arte religioso permaneció marginado de este proceso germinal de transformación.

A partir de esta coexistencia de la tradición colonial y de algunos intentos de renovación del espacio sagrado durante las primeras décadas de vida independiente, comienza a tomar cada vez más fuerza el rechazo a la tradición colonial, respondiendo, de este modo, a un contexto de construcción nacional más amplio. Para este momento, el proceso inicial de organización de la república se había estabilizado y una vez finalizada la guerra contra la Confederación Perú-boliviana (1836-1839) se instaló el debate público sobre educación, conocimiento científico del territorio, las artes, política, ortografía, organización social, incluyendo el papel de la religión, ámbitos que fueron dando forma al proyecto nacional ${ }^{22}$. Ante este escenario se consolida la idea de que la tradición colonial se trataba de un pasado que impedía el progreso de la nación, por lo que se hacía necesario impulsar un proceso regenerador que suprimiera el legado oscurantista de la monarquía española ${ }^{23}$. Una de las manifestaciones de este fenómeno fue el desprecio por la pintura, la escultura y la arquitectura colonial. Se instaló en el discurso de la élite la idea de que era necesario suprimir lo que se consideraba modelos artísticos aberrantes que deformaban el gusto de la población ${ }^{24}$.

Uno de los primeros juicios en esta dirección fue el del intelectual y político argentino Juan Bautista Alberdi ${ }^{25}$, quien, durante su prolongada residencia en Chile publicó

pp. 87-111; Alfredo Benavides, "En torno a la imaginería española e hispanoamericana", en Boletín de la Academia Chilena de la Historia, n. ${ }^{\circ}$ 40, Santiago, 1949, pp. 91-116; Fernando Guzmán, "Imaginería y retablos después de la emancipación”, en Marcial Sánchez (ed.), Historia de la Iglesia en Chile. La Iglesia en tiempos de la Independencia, Santiago, Editorial Universitaria, 2010, tomo II, pp. 333-346.

${ }^{21}$ Fernando Guzmán, "Religiosidad y arte durante el siglo XIX en Santiago de Chile", en Marcial Sánchez (ed.), Historia de la Iglesia en Chile. Los nuevos caminos: la Iglesia y el Estado, Santiago, Editorial Universitaria, 2011, tomo III, pp. 693-704.

${ }^{22}$ Ana María Stuven, "La generación de 1842 y la conciencia nacional chilena", en Revista de Ciencia Política, vol. IX, n. ${ }^{\circ}$ 1, Santiago, 1987, pp. 61-80. Véase también: Gabriel Cid, "La nación bajo examen. La historiografía sobre el nacionalismo y la identidad nacional en el siglo XIX chileno", en Polis Revista Latinoamericana, . $^{\circ} 32$, Santiago, 2012, pp. 1-17.

${ }^{23}$ Lastarria, Investigaciones..., op. cit., p. 134; José Victorino Lastarria, Recuerdos literarios: Datos para la historia literaria de la América española i del progreso intelectual en Chile, Santiago, Librería de M. Servat, 1885, p. 392. Para este tema se puede consultar: María Francisca Vergara, El proyecto artístico en el desarrollo educacional chileno a mediados del siglo XIX, Santiago, Pontifica Universidad Católica de Chile, 2005. Acerca de la reacción contra la cultura colonial se pude leer: Hernán Godoy, La cultura chilena, Santiago, Editorial Universitaria, 1984, p. 321. Para profundizar en el debate en torno al papel del legado español en la república y el uso de la historia como herramienta discursiva, véase: Gertrude Yaeger, "Sobrellevar el pasado español. Liberalismo latinoamericano y la carga de la historia colonial en el siglo XIX: el caso chileno", en Gabriel Cid y Alejandro San Francisco (eds.), Nación y nacionalismo en Chile, Santiago, Centro de Estudios Bicentenario, 2009, vol. 1, pp. 117-136.

${ }^{24}$ Acerca de los matices sobre esta discusión se puede consultar: Constanza Acuña, "Estudio introductorio presentación y notas", en Constanza Acuña (ed.), Perspectivas sobre el coloniaje, Santiago, Ediciones Universidad Alberto Hurtado, 2013, pp. 7-19.

${ }^{25}$ Juan Bautista Alberdi (1810-1884). Véase: Jorge M. Mayer, Alberdi y su tiempo, Buenos Aires, Eudeba, 1963; Bernardo Canal Feijoó, Alberdi, la proyección sistemática del espíritu de Mayo, Buenos Aires, Losada, 1961; Milcíades Peña, Alberdi, Sarmiento y el 90. Límites del nacionalismo argentino en el siglo XIX, Buenos Aires, Fichas, 1972. 
Veinte días en Génova (1845), libro en el cual señala que no es posible comparar las obras de arte religioso que pudo ver en Europa con "Los toscos y groseros trabajos de escultura que conocemos por acá" ${ }^{\prime 26}$. Con aún mayor claridad se expresó algunos años después Miguel Luis Amunátegui, intelectual y político chileno, en sus "Apuntes sobre lo que han sido las bellas artes en Chile" (1849), al afirmar: "Nos llegan de cuando en cuando pacotillas bien surtidas de cuadros quiteños de todos tamaños"27. Por su parte, Domingo Faustino Sarmiento, intelectual y político argentino que residió en Chile casi veinte años, en perfecta sintonía con los autores anteriores, emite la siguiente sentencia ante la vista de las iglesias de la Ciudad Eterna: "La artística Roma se cubriría la cara de vergüenza, si viera erigidos en alto algunos de nuestros crucifijos, con sus formas bastardas que rebajan la dignidad del Hombre Dios" ${ }^{\prime 28}$.

El clero de mayor cultura, como queda reflejado en la documentación de la catedral de Santiago, se habría plegado a este sentimiento contrario a la tradición colonial: "el restablecimiento de la antigua anda vestida de género vendría a esterilizar los esfuerzos de cuarenta años por desterrar de las iglesias las imágenes vestidas de género" ${ }^{29}$. El documento no da cuenta de las motivaciones que los canónigos de la catedral tuvieron para sostener esta clara política de supresión de ciertas formas del arte religioso colonial, sin embargo, a las posibles motivaciones estéticas se debieron agregar otras de índole religiosa. Es plausible que esta línea de acción esté vinculada al rechazo hacia aquellas obras concebidas para producir efectos ilusionistas y promover una piedad emocional. La necesidad de purificar la vida religiosa de ciertas manifestaciones heredadas de los tiempos coloniales es un tópico que se puede identificar en los escritos de algunos eclesiásticos chilenos del periodo. El rechazo a las imágenes vestidas quedó recogido de modo expreso en el Sínodo de Ancud, celebrado el año 1851, en cuyo texto se afirma que las imágenes religiosas "no necesitan del adorno postizo de vestidos" ${ }^{30}$. Monseñor José Ignacio Víctor Eyzaguirre, por su parte, se escandaliza de lo observado por él en una procesión: "una piedad más ilustrada -señala - trabajaría por desterrar de tales ceremonias todo lo que les acompaña de profano y repugna a la fe que las inspira y las dirige" ${ }^{31}$; expresión que englobaría con su juicio crítico a los bailes religiosos, las imágenes de vestir y todas las costumbres de piedad a ellas asociadas. En el Manual del párroco americano, publicado en 1844 por el sacerdote Justo Donoso, futuro obispo de La Serena, al referirse a la necesidad de

\footnotetext{
${ }^{26}$ Juan Bautista Alberdi, Veinte días en Génova, Valparaíso, Imprenta del Mercurio, 1845, p. 101.

${ }^{27}$ Miguel Luis Amunátegui, "Apuntes sobre lo que han sido las bellas artes en Chile. Historia de la Pintura y Escultura desde la Colonia al Siglo XX”, en Revista de Santiago, tomo III, Santiago, 1849, p. 45.

${ }^{28}$ Domingo Faustino Sarmiento, Viajes en Europa, África i América, Santiago, Imprenta de Julio Belín i Cia, 1849, vol. 1, pp. 414. Sobre Domingo F. Sarmiento y las bellas artes se puede ver: María Isabel Baldasarre, Imágenes del arte europeo en los Viajes de Domingo Faustino Sarmiento, 2004. Disponible en https://mundoclasico.com/articulo/6144/Imágenes-del-arte-europeo-en-los-Viajes-de-Domingo-Faustino-Sarmiento [fecha de consulta: 30 de mayo de 2021]. En particular sobre Roma: Giovanna Capitelli, "Domingo Faustino Sarmiento negli atelier degli artisti romani (1847)", en Elisa Camboni (ed.), Carlo de Paris (1800-1861), Roma, Campisano Editore (en prensa).

29 “Acuerdos", Santiago, 8 de noviembre de 1887, Archivo de la Catedral de Santiago (en adelante ACS), Libro de actas del Cabildo, n. ${ }^{\circ} 14$.

${ }^{30}$ Fernando Retamal, El primer sínodo chileno de la época republicana. Ancud, 1851, Santiago, Ediciones Universidad Católica, 1983, p. 126

${ }^{31}$ Eyzaguirre, Los intereses católicos..., op. cit., tomo I, p. 4.
} 
honrar las iglesias, precisa que "hanse de prohibir los entretenimientos o diversiones teatrales, las máscaras, las solemnidades menos decentes, los cantos de niñas y todo acto profano" "32. En el Sínodo de Ancud de 1851, convocado por monseñor Justo Donoso mientras era obispo de esa ciudad, prestó especial atención a las prácticas de piedad que se realizaban en los templos, prohibiendo los bailes religiosos en su interior ${ }^{33}$. En el Tratado de los fundamentos de la Fé, escrito en 1857 por José Manuel Orrego, quien sería luego obispo de La Serena, el autor declara que "el culto esterno ha dado orijen a mil absurdas, ridículas y detestables supersticiones", que deben ser desterradas ${ }^{34}$. Los rasgos de una piedad reformada debieran ser el énfasis en la interioridad y la preferencia por las prácticas normadas por la Iglesia; algunas de las manifestaciones concretas de este proceso fueron la promoción de una piedad romántica y de carácter cada vez más priva$\mathrm{do}^{35}$. El análisis de los vínculos entre los modelos artísticos y arquitectónicos romanos y las nuevas prácticas religiosas no es un asunto que aborde el presente trabajo, cuyo objetivo -menos ambicioso- es comprender el papel que representaron los modelos romanos en la materialización de este anhelo de reforma del espacio y la imagen sagrada, proceso que suponía la supresión de las formas coloniales.

En estos asuntos existió un significativo grado de coincidencia entre los miembros de una élite atravesada por agudas divergencias. Las inclinaciones regalistas o ultramontanas, así como las posturas liberales o conservadoras, eran fuentes de división al interior del clero, entre los intelectuales, entre los miembros de un mismo partido, así como entre el gobierno y la Iglesia ${ }^{36}$. No obstante, muchos se encontraban, de un modo u otro, en la crítica al arte y la piedad colonial. Se debe tener en cuenta que las motivaciones de las críticas de Miguel Luis Amunátegui o Domingo Faustino Sarmiento no son las mismas que impulsaron al Cabildo de la catedral de Santiago a suprimir las imágenes de vestir. Sin embargo, esta diversidad de intereses no fue obstáculo para encontrar en la reforma de las prácticas de piedad y la transformación del espacio y la imagen sagrada, un ámbito de convergencia. Es cierto que, como lo analiza Sol Serrano, el incendio de la iglesia de La Compañía, ocurrido en 1863, al suscitar enconadas discusiones en torno a la promoción de un culto religioso irracional que habría sido el causante de la tragedia, mostró -en apariencia- a una Iglesia que defendía el pasado colonial frente a políticos e intelectuales que promovían la erradicación de estas manifestaciones ${ }^{37}$. La postura dominante al interior de la Iglesia fue la de un impulso reformador que evita el ataque frontal a las viejas soluciones, quizá por un temor, nunca formulado, a suscitar conflictos con una parte del clero y con una feligresía que no estaba dispuesta a renunciar a sus prácticas ni a sus antiguas y veneradas imágenes.

La documentación citada da cuenta de la forma en que la élite intelectual, de modo particular un puñado de obispos y sacerdotes, fue delineando las transformaciones que

\footnotetext{
${ }^{32}$ Justo Donoso, Manual del párroco americano, Santiago, Imprenta del progreso, 1844, p. 54.

${ }^{33}$ Retamal, op. cit., p. 140-141.

${ }^{34}$ José Manuel Orrego, Tratado de los fundamentos de la Fé. Segunda edición revisada y mejorada, La Serena, Imprenta de La Serena, 1877, p. 73.

${ }^{35}$ Serrano, ¿Qué hacer..., op. cit., pp. 39-44 y 135-141.

${ }^{36}$ Op. cit., pp. 23-26 y 33-34.

${ }^{37}$ Op. cit., pp. 32-47.
} 
pretendía impulsar en las prácticas de piedad, el espacio sacro y las imágenes religiosas, con el objetivo de dotarlas de las condiciones adecuadas para ser un aporte y no una rémora en la construcción de una nación moderna. Pero, al mismo tiempo, cada una de esas referencias testimonia una silenciosa resistencia a dichos cambios. Los documentos dan cuenta de que aún persisten los bailes religiosos con sus mascaradas, y las comunidades siguen presionando para sacar en procesión a las viejas imágenes vestidas y con cabello natural. En suma, la necesidad de regenerar el espacio y la imagen sagrada es un consenso construido por unos pocos que pretenden imponer su punto de vista a una población ajena a dicha reflexión.

Para vencer esta resistencia era indispensable contar con un nuevo modelo de espacio e imagen sacra que suplantara al que se consideraba defectuoso. Domingo Faustino Sarmiento, en su diario de viaje, propuso a las iglesias de la Ciudad Eterna como referente, pues, en sus "altares se exponen a la veneración pública, tan sólo estatuas de bronce o mármol, o cuadros ejecutados por los más grandes artistas: de este modo la religión se muestra grande por sus símbolos"38. Benjamín Vicuña Mackenna, quien llegó a ser intendente de Santiago entre 1872 y 1875, luego de admirar las esculturas de Antonio Canova, se refiere, a mediados del siglo XIX, a la basílica de San Pablo Extramuros como "una espléndida iglesia de estilo moderno como la Magdalena de París"39; comentario que sitúa el esfuerzo historicista de reconstrucción de la basílica como un modelo que debía ser emulado. Un sacerdote jesuita del Colegio de San Ignacio, al opinar acerca de las características que debieran tener las imágenes de los altares de la nueva iglesia del Colegio, señalaba que "conviene más bien fuesen estatuas como son en Roma"40. Estos nuevos edificios e imágenes que debían florecer en tierra chilena estarían revestidos del prestigio multidimensional de Roma: depositaria de la tradición clásica, emporio artístico de Europa y capital del mundo católico.

A estos ámbitos se debe agregar la carga particular que tuvo para Chile la Roma de Pío IX, Papa que los chilenos habían conocido, pues -siendo el joven sacerdote Giovanni Maria Mastai Ferretti- había residido en Santiago durante los años 1824 y 1825, como miembro de la misión diplomática presidida por monseñor Juan Muzi ${ }^{41}$. Toda esta carga de significados impregnaba a los objetos, imágenes y edificios que de una u otra forma se vinculaban con la Ciudad Eterna. Resultaba necesario, por tanto, contar con arquitectos, pintores y escultores que llevaran adelante la tarea de regenerar la imagen y el espacio sagrado, teniendo a Roma como modelo.

Debe tenerse en cuenta que, a pesar de las tensiones que provocaba la discusión en torno al patronato, las relaciones entre la República de Chile y la Santa Sede se en-

\footnotetext{
${ }^{38}$ Sarmiento, op. cit., p. 412; Capitelli, "Domingo Faustino...", op. cit.

${ }^{39}$ Benjamín Vicuña Mackenna, Páginas de mi diario durante tres años de viaje, Santiago, Imprenta del Ferrocarril, 1856, pp. 238, 242 y 244.

40 "Consultas sobre la Construcción de la Iglesia", en Archivo Provincial de la Compañía de Jesús en Chile (en adelante APCJ), 2/J/300, carpeta 11 .

${ }^{41}$ Sobre la misión Muzi se puede ver en particular: Pedro de Leturia y Miguel Batlori, La primera misión pontificia a Hispanoamérica. 1823-1825. Relación oficial de Mons. Giovanni Muzi, Ciudad del Vaticano, Biblioteca Apostólica Vaticana, 1963; Giacomo Martina, "La prima missione pontificia nell'America Latina", in Archivum Historiae Pontificiae, vol. 32, Roma, 1994, pp. 149-193; Francisco Martí Gilabert, "La misión en Chile del futuro Papa Pío IX: llegada a Santiago, regreso y desenlace (1824-1832)”, en Anuario de Historia de la Iglesia, n. ${ }^{\circ} 10$, Santiago, 2001, pp. 281-321.
} 
contraban en un buen momento al promediar el siglo XIX. Dos hitos relevantes fueron el reconocimiento oficial de la Independencia de Chile y la elevación de Santiago a la categoría de Arzobispado, ambos en el año $1840^{42}$. Por otra parte, la presencia en Roma, entre 1847 y 1850, de la misión diplomática conducida por Ramón Luis Irarrázaval permitió alcanzar acuerdos significativos en aspectos específicos ${ }^{43}$, allanando así el desarrollo de vínculos comerciales y culturales.

El catastro completo de todas las pinturas y esculturas de producción romana que llegaron a Chile durante la segunda mitad del siglo XIX, aún está por ejecutarse. Sin embargo, además de los conjuntos más importantes, ubicados en la Recoleta Dominica y en la iglesia de San Ignacio, se conserva una gran cantidad de obras específicas en diversos sitios. En la catedral de Santiago, por ejemplo, se encuentra una escultura de Giovanni Strazza, que representa a monseñor José Alejo Eyzaguirre orante, un altar de mármol obsequiado por monseñor José Ignacio Víctor Eyzaguirre -y que albergaba en origen una pintura de la última cena ejecutada por Ignazio Tirinelli-, el retrato de Pío IX realizado por Francesco Podesti ${ }^{44}$, además de la pintura de la Virgen del Carmen entregando el escapulario a san Simón Stok, obra del pintor francés -activo en RomaJacques Pilliard. Por otra parte, el catastro de bienes patrimoniales del Arzobispado de Santiago, realizado entre los años 2012 y 2014, permitió identificar, entre otras obras, pinturas de Paolo Mei, Pietro Gagliardi y Prospero Piatti, así como esculturas de Giovanni Anderlini y Giulio Tadolini ${ }^{45}$.

Una de las matrices culturales que subyacen al prestigio devocional y artístico de Roma está representada por la exportación global de las reliquias tomadas de las catacumbas cristianas. El fenómeno de la difusión planetaria de estas reliquias durante el siglo XIX, como muestran los estudios conducidos por Philippe Boutry -en forma especial durante la primera parte del siglo-, es parte integral de ese complejo proceso de resacralización del orbe católico que afecta, después de la traumática fase de las guerras napoleónicas, tanto a Europa como América ${ }^{46}$. En estos objetos de exportación tan par-

${ }^{42}$ Marcial Sánchez Gaete, "Relaciones Iglesia Estado en el Chile del siglo XIX", en Revista Pluri, vol. 1, n. ${ }^{\circ}$ 1, San Pablo, 2018, p. 195.

${ }^{43}$ Carlos Oviedo Cavada, La misión Irarrázaval en Roma 1847-1850. Estudio histórico canónico de las relaciones de Iglesia y Estado en Chile, Santiago, Instituto de Historia de la Pontificia Universidad Católica, 1962; Carlos Salinas, "Los concordatos celebrados entre la Santa Sede y los países latinoamericanos durante el siglo XIX”, en Revista de Estudios Histórico-Jurídicos, vol. XXXV, Valparaíso, 2013, pp. 251-252.

${ }^{44}$ Capitelli, Mecenatismo pontificio..., op. cit., pp. 162-165.

${ }^{45}$ Fernando Guzmán, María José Castillo, Claudio Díaz, Constanza López, Marcial Sánchez y Katherine Vyhmeister, "Catastro de bienes patrimoniales muebles del Arzobispado de trabajo", documento de trabajo inédito, 2015.

${ }^{46}$ Philippe Boutry, "Les saints des Catacombes: Itinéraires français d'une piété ultramontaine (1800-1881)", in Mélanges de l'Ecole française de Rome. Moyen-Age, Temps modernes, vol. XCI, n. ${ }^{\circ}$ 2, Roma, 1979, pp. 875-930; Philippe Boutry, "Corps saints et recharges sacrales: Geneviève, Germaine, Theudosie et les autres", in Yves Le Fur (ed.), “La mort n'en saura rien”: Reliques d'Europe et d'Océanie, Catalogue d'exposition, Paris, Musée National des Arts d'Afrique et d'Océanie, 12 octobre 1999 au 24 janvier 2000, Paris, Editions de la Réunion des Musées Nationaux, 1999, pp. 83-96; Philippe Boutry, "Une recharge sacrale: Restauration des reliques et renouveau des polémiques dans la France du XIXe siècle", in Philippe Boutry, Pierre-Antoine Fabre et Dominique Julia (eds.), Reliques modernes: Cultes et usages chrétiens des corps saints des réformes aux révolutions, Paris, Éditions de l'École des Hautes Études en Sciences Sociales, 2009, vol. I, pp. 121174. Para una orientación acerca de la circulación de las reliquias romanas en época prenapoleónica, véase: 
ticulares, el culto se basa en un prestigio devocional construido con habilidad en el encuentro entre valor estético, valor sagrado y valor político, definiendo así una verdadera política artística de la religión ${ }^{47}$.

El caso de la reliquia de san Vicente -que llegó a Chile en diciembre de 1864 y se colocó en la capilla doméstica de la iglesia de San Ignacio, en Santiago- ofrece en muchos sentidos un ejemplo casi de manual ${ }^{48}$. Los estudiantes del colegio jesuita no fueron llamados a venerar solo los restos humanos de un glorioso mártir, sino con ellos un objeto sagrado, una estatua de cera que los contenía, protegida por una vitrina, artefacto similar a muchos otros que Roma exportó a todo el mundo durante el siglo XIX. Solo en Santiago hay al menos otros dos casos, en la iglesia capuchina y en la catedral. Las referencias culturales para introducir el culto de los primeros mártires cristianos romanos a Chile fueron más políticas que religiosas, más fieles a una retórica ultramontanista que se opuso -en su actitud militante- tanto al modelo colonial español del pasado como al modelo liberal estadounidense de un posible futuro. El himno que el poeta chileno Carlos Morla Vicuña habría escrito en honor a la reliquia de san Vicente ("No, no es, niño, un destierro este suelo, / Nuestra patria es tu patria tambien / Si; contigo, Anjel puro del cielo / Un amor nos enlaza, una fé") parece evocar la presencia de un "americanismo" diferente: un americanismo romano, que mira a la capital del catolicismo universal ${ }^{49}$.

Sin duda, debe tenerse en cuenta que la opción por Roma no era la única disponible: los estrechos vínculos diplomáticos con Francia, así como la creación de instituciones locales orientadas a la formación de artistas y arquitectos, ofrecían alternativas viables. Es cierto que los modelos franceses de arte y arquitectura religiosa tuvieron cada vez más presencia en Chile al avanzar el siglo XIX; sin embargo, se debe considerar que los ejemplos más relevantes corresponden a las últimas dos décadas de la centuria y que nunca contaron con la entusiasta crítica que despertaron algunos edificios de influjo romano, como la iglesia de la Recoleta Dominica. Si bien la creación de la Academia de Pintura en 1849 se transformó en un hito importante para lograr erradicar los resabios del arte colonial ${ }^{50}$, al instituirse como "un acontecimiento inaugural del arte y la civilización en Chile"s1, no parece haber empujado un cambio significativo en el ámbito del arte religioso: salvo algunas excepciones, los artistas formados en esta casa de estudio concentraron su actividad

Stéphane Baciocchi et Christophe Duhamelle (eds.), Reliques romaines: invention et circulation des corps saints des catacombes à l'époque moderne, Roma, École Française de Rome, 2016.

${ }^{47}$ Cracolici, "Nuestra patria...", op. cit., pp. 156-159. Sobre el aspecto estético, mucho menos estudiado, de las reliquias romanas extraidas desde las catacumpas, véase: Boutry, "Corps saints et recharges...", op. cit., p. 92; Wolfgang Brückner, "Die Katakomben im Glaubensbewußtsein des katholischen Volkes: Geschichtsbilder und Frömmigkeitsformen”, in Römische Quartalschrift für christliche Altertumskunde und Kirchengeschichte, vol. LXXXIX, Herder, 1994, pp. 287-307; Massimiliano Ghilardi, Subterranea civitas. Quattro studi sulle catacombe romane dal Medioevo all'età moderna, Roma, Edizioni dell'Ateneo, 2003, p. 115.

${ }^{48}$ Cracolici, “"Nuestra patria...", op. cit.

${ }^{49}$ Carlos Morla Vicuña, Himno, versos 17-20, en Cracolici, "Nuestra patria...”, op. cit., p. 164.

${ }^{50}$ Josefina de la Maza, De obras maestras y mamarrachos, Santiago, Ediciones Metales Pesados, 2014, p. 30; Amunátegui, op. cit., p. 38; Alejandro Ciccarelli, "Discurso pronunciado en la inauguración de la Academia de Pintura por su director D. Alejandro Cicarelli", Santiago, Imprenta Chilena, 1849, en Josefina de la Maza, La inauguración de la Academia, Santiago, Ediciones Universidad Alberto Hurtado, 2013, p. 16.

${ }^{51}$ Pablo Berríos, Eva Cancino, Claudio Guerrero, Isidora Parra, Kaliuska Santibáñez y Natalia Vargas, Del taller a las aulas. La institución moderna del arte en Chile (1797-1910), Santiago, LOM Ediciones, 2009, p. 95. 
en el retrato, el paisaje y la historia nacional. Sin duda hay excepciones, como el caso del pintor Miguel Campos, quien realizó un ciclo de la vida de Cristo que se encuentra en la iglesia de San Francisco en Santiago, así como los cuatro evangelistas que se encuentran bajo la cúpula de la iglesia de la Recoleta Dominica, entre otras obras. También se puede mencionar a Pedro León Carmona, quien realizó lienzos de pintura religiosa como el Sagrado Corazón de la iglesia de las Agustinas, la Virgen del Carmen en San Ignacio, o la pintura del mismo tema en la iglesia de Nuestra Señora del Carmen. No obstante, la demanda por imágenes religiosas modernas parece haber superado la oferta local. Por tanto, la deseada renovación del arte religioso no podía basarse solo en la producción de artistas chilenos; la mayoría de los artistas formados en la Academia no trabajó temáticas religiosas y los quiteños activos en el país realizaban obras inaceptables para la nueva sensibilidad. Era necesario adquirir piezas fuera de Chile para satisfacer los requerimientos locales. Este ingreso de pinturas o esculturas de temática religiosa no se restringió a satisfacer las necesidades del culto religioso, pues algunas de ellas fueron adquiridas - de modo especial las copias de obras célebres- por consideraciones de carácter artístico ${ }^{52}$. Este proceso de secularización de las imágenes religiosas es un asunto de particular interés que, sin embargo, desborda el marco del presente texto.

A la formación de pintores y escultores debía sumarse la preparación sistemática de arquitectos nacionales. El 17 de noviembre de 1849 se decretó la creación del curso de Arquitectura, cuyo primer profesor fue el francés François Brunet Debaines, quien ocupó el cargo de arquitecto de gobierno desde 1848 hasta su muerte en $1855^{53}$. A pesar de haber estado asociada desde sus inicios a la Facultad de Ciencias Matemáticas y Físicas de la Universidad de Chile, el año 1858 la disciplina se incorporó como una de las áreas de la Sección Universitaria de Bellas Artes, lo que buscó dar al proceso formativo una mayor solidez institucional ${ }^{54}$. Arquitectos franceses, como François Brunet Debaines o su sucesor, Lucien Hénault, junto a profesionales chilenos ${ }^{55}$, levantaron edificios de uso

\footnotetext{
${ }^{52}$ Sandra Accatino, "Una copia, una cita, un original", en Sandra Accattino y Sergio Guarino (eds.), Caravaggio en Chile, luz del Barroco, Santiago, Museo Nacional de Bellas Artes, 2016, pp. 60-76.

${ }^{53}$ Virginio Arias, Memoria histórica de la Escuela de Bellas Artes de Santiago de Chile, Santiago, Imprenta Cervantes, 1908, p. 7; Myriam Waisberg, La clase de arquitectura y la Sección de Bellas Artes: en torno al centenario de la creación de la Sección de Bellas Artes de la Universidad de Chile, 1858-1958, Santiago, Universidad de Chile, Facultad de Arquitectura y Urbanismo, Instituto de Teoría e Historia de la Arquitectura, 1962, p. 35; Amarí Peliowski, "Arquitectura, civilización y barbarie: Brunet Debaines como comentador social a mediados del siglo XIX en Chile", en Revista 180, n. ${ }^{\circ} 42$, Santiago, 2018, pp. 76-87.

${ }^{54}$ Arias, op. cit., p. 5. Las primeras décadas de existencia del curso de Arquitectura presentaron, a pesar de estos esfuerzos, serias dificultades. Las principales razones fueron la persistente escasez de alumnos y la dificultad de conciliar la organización de las clases con los trabajos públicos exigidos a François Brunet Debaines en su contrato. El curso experimentó una situación similar con Lucien Hénault a cargo. Estas circunstancias explican que cerrara entre 1857 y 1858, y entre 1866 y 1872. Waisberg, op. cit., pp. 41-45; Amarí Peliowski, "Lo bello o lo útil. Ideologías en disputa en torno a la creación del primer curso universitario de arquitectura en Chile, 1848-1853", en Historia, n. ${ }^{\circ}$ 51, vol. II, Santiago, 2018, p. 514.

${ }_{55}^{5}$ No es posible pensar, para este periodo, en un número importante de arquitectos chilenos en la escena nacional, puesto que la misma inestabilidad del curso de Arquitectura impidió que hubiese un flujo de profesionales graduados como arquitectos desde la Universidad de Chile. Ricardo Brown, el primer arquitecto en recibir su título universitario, se graduó en 1862 y fue por años el único. Sin embargo, fue usual que alumnos y egresados del curso trabajaran junto a François Brunet Debaines y Lucien Hénault en sus respectivas obras.
} 
público y privado que se adaptaron a nuevas demandas. En forma paulatina, estos arquitectos posibilitaron la adaptación de las ciudades chilenas a un ideario modernizador que privilegiaba nuevas formas y espacios de sociabilidad ${ }^{56}$. La construcción de iglesias no quedó ajena a este proceso de transformación, ámbito en el que tuvieron un papel destacado arquitectos formados en Roma, como Eusebio Chelli e Ignazio Cremonesi ${ }^{57}$.

Durante la segunda mitad del siglo XIX el espacio arquitectónico religioso sufrió alteraciones importantes en la mayoría de las ciudades de Chile. Se incorporaron nuevos sistemas constructivos y materiales, cambios entre los que destaca el paulatino reemplazo del adobe por el ladrillo, así como la modificación de los sistemas estructurales de las techumbres ${ }^{58}$. De la mano de la renovación de las materialidades y técnicas se produjo un abandono del modelo de iglesia de planta angosta y alargada, con muros de poca altura e interiores oscuros, por otras más amplias, altas e iluminadas. Las transformaciones también fueron visibles en el exterior de los templos, de modo especial por la incorporación de torres más esbeltas e integradas al edificio, en contraste con las estructuras coloniales, en muchas ocasiones exentas y de cuerpos más robustos y bajos. Por otra parte, un gran número de las iglesias que se construyeron durante la segunda mitad del siglo XIX fueron concebidas con apego a los cánones clásicos, algo que se puede observar en las distintas escalas de estos proyectos, desde su composición arquitectónica hasta los detalles y ornamentos. En este vasto proceso de transformaciones, la presencia de arquitectos de la península itálica como Eusebio Chelli, Ignazio Cremonesi, Diego Chuffa [Ciuffa] y Eduardo Provasoli, fue decisiva. También en Roma, el purismo clásico se había hecho visible en la arquitectura religiosa durante la década del cuarenta, en forma especial alrededor de las obras de reconstrucción de la basílica de San Pablo Extramuros. Pero, lo que en la Ciudad Eterna había sido un cuidadoso resurgimiento

${ }^{56}$ Katherine Vyhmeister, "Usos y apropiaciones del espacio urbano en Santiago de Chile: la transformación de La Cañada en Alameda de las Delicias", en Bifurcaciones, n. ${ }^{\circ}$ 19, Santiago, 2015, p. 5.

${ }^{57}$ Dentro de la escasa producción historiográfica que abarca la historia de la arquitectura del siglo XIX en Chile, se ha establecido una tendencia sobre el origen de los arquitectos que desarrollaron los proyectos y estuvieron a cargo de la construcción tanto de edificios civiles como de iglesias a lo largo del país, identificándose el primer caso con arquitectos franceses y el segundo con profesionales provenientes de la península itálica. Sin embargo, resulta interesante destacar que, en agosto de 1856, algunos meses después de la muerte de François Brunet Debaines, el ministro de Justicia, Culto e Instrucción Pública de Chile, Francisco Javier Ovalle, envió una carta a Manuel Blanco Encalada, ministro Plenipotenciario de Chile en Francia, con la recomendación de dar preferencia a la contratación de un arquitecto romano como reemplazo para el puesto de arquitecto de gobierno. En último término, y por circunstancias más azarosas que premeditadas, la gestión de Manuel Blanco Encalada tuvo como resultado la contratación del francés Lucien Hénault. Sin embargo, no se debe pasar por alto el hecho de que la solicitud de un arquitecto romano para ocupar el cargo de proyección y dirección de edificios públicos, así como también de la formación académica de los futuros arquitectos nacionales, provino de un ministro de Estado. Carta del ministro Plenipotenciario de Chile en Francia Manuel Blanco Encalada al ministro de Justicia, Culto e Instrucción Pública Francisco Javier Ovalle, Hamburgo, 27 de agosto de 1856, en Archivo Nacional Histórico, Fondo Archivo Fernández Larraín, vol. 67, pieza 36; Katherine Vyhmeister, "Historia cultural urbana: una propuesta interdisciplinaria para el estudio del Santiago de la segunda mitad del siglo XIX”, en Raquel Abella, Angela Brandão y Fernando Guzmán (eds.), $L a$ historia del arte en diálogo con otras disciplinas, Santiago, Museo Histórico Nacional / Universidade Federal de São Paulo / Universidad Adolfo Ibáñez / CREA, 2016, p. 143.

${ }^{58}$ María José Castillo, Evolución de los sistemas constructivos de los templos religiosos en la zona central del Chile siglos XVI al XIX, Santiago, Centro de Estudios Bicentenario, 2018, pp. 49-100. 
filológico de una larga tradición - proceso puesto en crisis por la afirmación de la arquitectura barroca- en Chile el mismo movimiento antibarroco promovió un lenguaje nuevo e importado.

Junto al aporte específico de los arquitectos, pintores y escultores, se encuentra la actividad de promoción de las nuevas formas que realizaron algunos religiosos, como los dominicos Juan O’Brien, Francisco Álvarez y Domingo Aracena; los obispos José Manuel Orrego y Justo Donoso, o el sacerdote José Ignacio Víctor Eyzaguirre ${ }^{59}$, quienes de distintas formas impulsaron la renovación del espacio y la imagen religiosa en Chile. En este ámbito merece una especial atención Camillo Domeniconi ${ }^{60}$, pintor de formación romana que vivió en Santiago entre 1830 y 1838, dedicado a la realización de retratos. Su presencia posterior en Roma lo transformó en un referente decisivo para los chilenos que visitaron la ciudad en las décadas del cuarenta y el cincuenta, oficiando de guía cultural y de agente para la adquisición de obras artísticas. En 1851 fue designado cónsul de Chile en Roma, nombramiento que reforzó el papel que ya venía cumpliendo. Sus vínculos latinoamericanos no se limitaron a Chile, pues en 1853 asumió como cónsul del Perú en la Ciudad Eterna. Un papel semejante habría desempeñado fray Juan O'Brien, dominico de origen irlandés que habría profesado en la Recoleta y que para mediados de siglo se encontraba en el convento de Santa Maria Sopra Minerva ${ }^{61}$. Habría sido un interlocutor clave para gestionar los encargos romanos del convento de la Recoleta Dominica. La actividad de estos agentes y sus vínculos con Chile es un asunto que aún está por estudiarse.

Los casos de espacio e imagen sagrada que ahora se analizarán permiten abordar distintas concreciones de este proceso, así como estudiar las reacciones de la población frente a los nuevos modelos. La iglesia de la Recoleta Dominica, dirigida por Eusebio Chelli, fue la perfecta concreción de la "romanidad". Las iglesias levantadas en la isla de Chiloé, de acuerdo con el patrón arquitectónico impuesto por fray Diego Chuffa [Ciuffa], son un testimonio de la pervivencia de las viejas imágenes coloniales en los nuevos espacios. La iglesia de San Ignacio en Santiago, obra de Eusebio Chelli, se presenta como un proyecto de renovación del espacio y la imagen sacra que, por su adaptación a la realidad local, puede ser replicado por iglesias que no cuentan con demasiados recursos. La iglesia nueva de Andacollo, obra del mismo arquitecto, fue levantada con el propósito de instalar un edificio que irradie "romanidad" y opere como contrapeso frente a las pintorescas expresiones de piedad popular características de esta localidad. Para finalizar, la capilla del Seminario Pontificio de Santiago, obra de Ignazio Cremonesi, que fue bendecida en 1898, permite observar la persistencia de unas pautas de validación, forjadas a mediados de la centuria, en las que Roma representa un papel fundamental.

\footnotetext{
${ }^{59}$ Fernando Guzmán y Valentina Ripamonti, "Mecenazgo de monseñor Eyzaguirre y la reforma del arte sagrado en Chile”, en Ana María Pimenta Hoffmann, Angela Brandão, Fernando Guzmán y Macarena Carroza (eds.), VII Jornadas de História da arte: coleções, arquivos e narrativas, Margem da Palavra, São Paulo, Universidade Federal de São Paulo / Museo Histórico Nacional / Universidad Adolfo Ibáñez / CREA, 2016, pp. 449-462.

${ }^{60}$ Federica Gioacomini, "Roma, Santiago, Lima e ritorno: i rapporti artistici tra l'Italia e il Sudamerca nell'attività di Camillo Domeniconi”, en Guzmán y Martínez, Vínculos artísticos..., op. cit., pp. 135-145.

${ }^{61}$ Capitelli, "Los 'pintores de Pio IX'...", op. cit., p. 48.
} 
El año 1851, solo dos años después de la formación de la Academia de Pintura y de la creación del curso de Arquitectura, y siete años antes de la creación de la clase de Escultura, los padres dominicos del convento de la Recoleta de Santiago ${ }^{62}$ encargaron al escultor Antonio Bisetti ${ }^{63}$, a través del padre Juan O'Brien ${ }^{64}$, la ejecución de una escultura de Nuestra Señora del Rosario en mármol ${ }^{65}$. La escultura de mármol de Antonio Bisetti debió contrastar con el resto de la ornamentación de la iglesia, de modo especial con el retablo donde debía ser albergada. Pareció necesario encargar a Roma un altar de mármol parar acoger la obra de Antonio Bisetti, además de otras dos esculturas con las efigies de santo Domingo de Guzmán y san Francisco de Asís; la primera fue realizada por el mismo Antonio Bisetti y la segunda por Carlo Chelli (Fig. 1). La llegada de estos trabajos a Chile, en el año $1853^{66}$, provocó un fuerte entusiasmo, cuyos ecos se pueden encontrar en la prensa de la época.

${ }^{62}$ Víctor Rondón, "Música y cotidianeidad en el convento de la Recoleta Dominica de Santiago de Chile en la primera mitad del siglo 19", en Revista Musical Chilena, vol. 53, n. ${ }^{\circ}$ 192, Santiago, 1999, p. 59. Sobre Eusebio Chelli, véanse: Mariano Campos, "La iglesia de la Preciosa Sangre. Aproximación al centenario de su edificación", en Boletín de la Academia Chilena de la Historia, n. ${ }^{\circ}$ 95, Santiago, 1984, p. 28; Capitelli, "Los 'pintores de Pio IX'...", op. cit.

${ }^{63}$ Sobre Antonio Bisetti se puede ver: Alfonso Panzetta, Atlante regionale degli scultori italiani dal Neoclassicismo al primo Novecento. Il Piemonte. Da Amedeo Lavy a Medardo Rosso, Torino, Adarte, 2008, p. 6. Algunas fuentes contemporáneas de Roma sobre sus obras se mencionan en Capitelli, "Los 'pintores de Pio IX'...", op. cit., p. 49, nota 24.

${ }^{64}$ Juan Andrés O'Brien es un personaje relevante en la historia de la comunidad latinoamericana en Roma, aún poco indagado. Ordenado sacerdote en 1827, e incorporado al séquito de monseñor Giovanni Muzi, era un dominico con residencia en el convento de Santa Maria Sopra Minerva. Gracias al magistrado sanjuanino Manuel Quiroga Carril, en 1828 fue, además, nominado 'agente cerca de Su Santidad del Sumo Pontífice de Roma' para la Argentina independentista. Cayetano Bruno, Historia de la Iglesia en la Argentina, Buenos Aires, Editorial Don Bosco, 1974, p. 199. La reciente consulta del Archivum Generales Ordines Praedicatorum (AGOP) de Roma (Provincia S. Laurentii M. de Chile, b. XIII.027092, fasc. 1826-1827) ha permitido individuar numerosas cartas de fray Juan: “Andrea O’ Brien, e del Rosario, Religioso Converso dell'Ordine de Predicatori, presente in Roma, figlio del convento di Santa Maria di Betlemme nella Provincia del Chili, nell'America Meridionale, e Procuratore di detta Provincia" (en particular es interesante la primera carta del 2 de enero de 1826, dirigida al papa León XII, en la que se lamenta de la pérdida de todos los bienes de los regulares: "Il governo si è impadronito di tutti i beni dei Regolari", y solicita poner a interés un capital de dos mil escudos para mantenerse de sus frutos durante su demora en Europa, sin verse obligado a consumir el capital que le servirá para financiar su viaje de retorno). Publicado en Capitelli, "Domingo Faustino...", op. cit.

${ }^{65}$ Capitelli, "Los 'pintores de Pio IX'...”, op. cit.; Capitelli, Mecenatismo pontificio..., op. cit., pp. 162165; Giovanna Capitelli, "Pittura romana dell'ottocento a Santiago del Cile. Addenda, segnalazioni, note", en Maria Lupi y Claudio Rolle (eds.), El Orbe Católico. Transformaciones, continuidades, tensiones y formas de convivencia entre Europa y América. Siglos IV-XIX, Santiago, RIL Editores / Pontificia Universidad Católica de Chile, Instituto de Historia, 2016, pp. 323-346.

${ }^{66}$ Ramón Ramírez, O.P., Los dominicos en Chile. Breve resumen de los hechos históricos, personajes, etc., Santiago, Editorial Universidad Técnica del Estado, 1976, p. 42. 
Figura 1

Altar mayor de la iglesia de la Recoleta Dominica

(1852-1853)

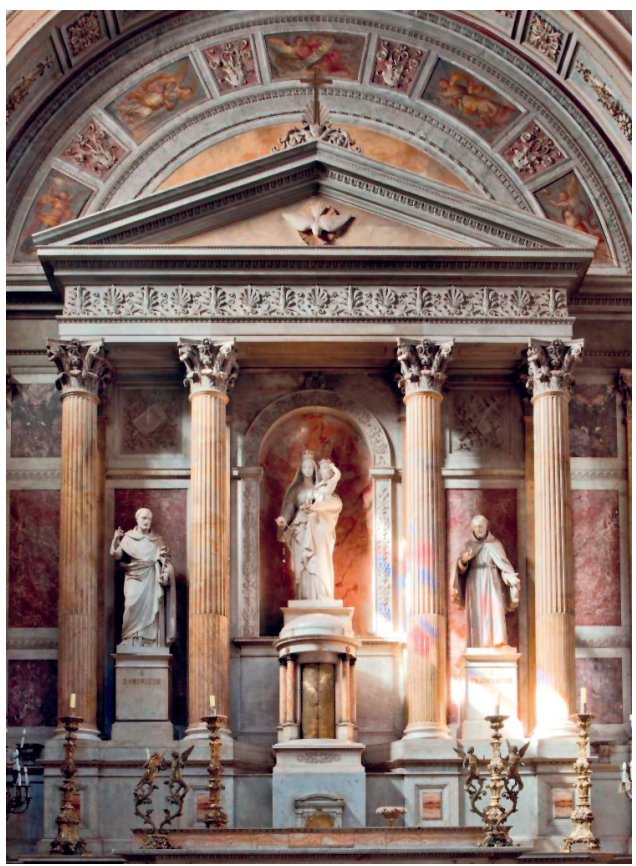

Fotografía: Giulio Archinà.

El culto de Pío IX:

La Recoleta Dominica

El nuevo retablo de mármol para la iglesia de la Recoleta Dominica, ejecutado por el arquitecto Eusebio Chelli, hermano del escultor de la efigie de san Francisco, llegó a Chile el año 1853. Se había formado en la Academia de San Lucas y había trabajado en las obras de la basílica de San Pablo Extramuros, de modo que conocía bien las orientaciones y prácticas de la arquitectura romana de mediados de la centuria, así como el ambiente artístico de la ciudad, de modo especial en lo que se refiere a la producción de imágenes sacras. Si bien el altar no habría sido instalado en la vieja iglesia de la Recoleta, su presencia en Santiago provocó entusiastas reacciones en la prensa. El purismo clásico de sus formas debió ser uno de los factores que favoreció la calurosa acogida, aunque se debe tener en cuenta que, en un país sin canteras de mármol, la materialidad de la estructura debió ser parte del origen de la admiración. El Mensajero, se refiere a la obra de Eusebio Chelli como "el soberbio altar mayor" ${ }^{67}$ o "el famoso altar de mármol

\footnotetext{
67 “Arquitectura sagrada. Segundo artículo”, en El Mensajero, n. ${ }^{\circ}$ 209, Santiago, 28 de enero de 1854.
} 
que hicieron construir en Europa que tantos elogios ha merecido por su trabajo y buen gusto" ${ }_{68}$. También se detienen a reconocer los méritos del arquitecto, "cuyo genio se revela en el suntuoso altar mayor, concepción suya y primorosa ejecución de su cincel" $"$.

El mismo año de la llegada del altar, los dominicos de la Recoleta decidieron encargarle a Eusebio Chelli el proyecto de una nueva iglesia, cuya maqueta se conserva en el Museo de la Recoleta Dominica. La idea de levantar un templo que reemplazara al construido a mediados del siglo XVIII la habría forjado el prior del convento, fray Francisco Álvarez, poco antes de encargar el altar y sus esculturas: "concibió en sus últimos años el valiente proyecto de edificar una nueva iglesia, más cómoda para los fieles que la que había, cuyo altar mayor debería ser de mármol, por ser más adecuado al culto divino" 70 , agregando luego que decidió comenzar los trabajos por el altar, "encargándolo a Roma, la patria de las bellas artes i del buen gusto, en donde podía trabajarse con mas ventajas que en cualquier otra parte" ${ }^{\text {" }}$. En noviembre de 1854, poco antes de la muerte de fray Francisco Álvarez, se puso la primera piedra y comenzaron las obras de un edificio que de inmediato concitó un ardiente apoyo (Fig. 2).

\section{FiguRA 2}

\section{Fachada de la iglesia de la Recoleta Dominica}

(1854-1883)

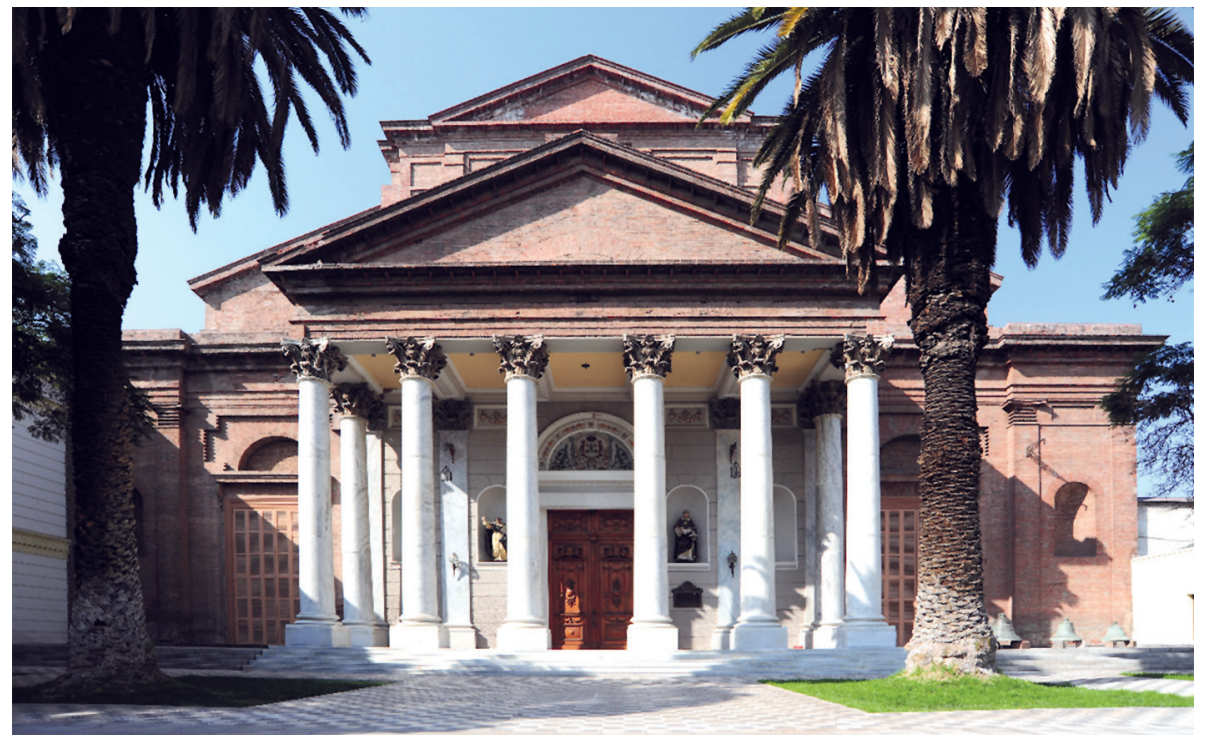

Fotografía: Giulio Archinà.

68 "Colocación de la primera piedra del Templo de la Recoleta Domínica", en El Mensajero, n. ${ }^{\text { }} 153$, Santiago, 22 de noviembre de 1853.

69"AArquitectura sagrada. Segundo artículo", op. cit.

${ }^{70}$ Fr. Domingo Aracena, Recuerdos del M.R.P. Maestro Dr. Fr. Francisco Alvarez prior y vicario general de la Recoleta Domínica, Santiago, Imprenta de Julio Belini i Cia, 1854, p. 46.

${ }^{71}$ Ibid. 
El entusiasmo de los redactores de la prensa local es desbordante y contrasta con los escasos comentarios que merecieron otras iglesias que se construyeron en el periodo. El Mensajero, a meses de colocada la primera piedra, publica un extenso artículo que comienza señalando lo mucho que se ha escrito acerca del nuevo templo, luego entrega una pormenorizada descripción del proyecto y termina afirmando: "La Recoleta Dominica contará con un templo el más grandioso de Sud-América, i el nacional o extranjero que lo visite repetirá siempre con admiración el nombre de Chelli" 72 . Dos meses después de lo publicado en El Mensajero, el diario El Mercurio presenta un artículo titulado "Construcción monumental"; el texto da cuenta de los avances del edificio y compitiendo en entusiasmo señala: "Será, pues, tal obra un templo y un museo, un trabajo tan sólido como soberbio"73. Monseñor José Ignacio Víctor Eyzaguirre, por su parte, señala que los dominicos están adornando "la capital de la República con el templo más suntuoso que hasta hoy se ha construido en el continente americano"74. Fray Domingo Aracena fue elegido nuevo prior del convento, de modo que sobre él recayó la responsabilidad de llevar adelante lo que el anterior prior había iniciado; de sus declaraciones acerca de la centralidad artística de Roma, así como sobre lo que de modo efectivo se ejecutó, se puede deducir que tenía una clara convicción del modelo arquitectónico y artístico que debía dar forma a la iglesia conventual que se levantaba.

El silencio frente a los demás templos y, por el contrario, el entusiasmo que despierta el proyecto de Eusebio Chelli, son elocuentes: la élite intelectual del país concibió el templo, desde su existencia en el papel, como un modelo artístico a seguir, tal como lo expresa El Mercurio: "La obra grandiosa del nuevo templo de la Recoleta Dominica que se construye y sobre el cual aún en su principio están fijas las miradas". El asunto, como lo recuerda el mismo periódico, no es solo artístico o arquitectónico, las formas que Eusebio Chelli levanta permitirían instaurar una nueva devoción, depurada de los rasgos preilustrados que tanto criticaba El Mercurio al comentar en sus páginas las procesiones y romerías; para el articulista del diario, en un templo como el que construían los dominicos "las ceremonias religiosas tendrán un mayor realce y participarán de un brillo poético y sobrehumano"

La llegada del altar y las tres esculturas de mármol, así como el inicio de la construcción del nuevo templo para el convento de la Recoleta Dominica, fueron factores que aceleraron la transformación del espacio sagrado en Chile. Los modelos para iniciar la regeneración de la arquitectura y el arte sagrado estaban presentes en la ciudad: un altar de mármol y la maqueta de un nuevo templo. Al mismo tiempo, comenzaba a estructurarse un discurso del que forman parte expresiones como suntuosidad, brillo poético o el realce de las ceremonias. El proyecto se completó con el encargo a talleres romanos de catorce pinturas representando los misterios del rosario (Fig. 3).

72 "Arquitectura sagrada. Segundo artículo", op. cit.

73 “Construcción monumental”, en El Mercurio, n. ${ }^{\circ}$ 7982, Santiago, 27 de marzo de 1854.

${ }^{74}$ José Ignacio Víctor Eyzaguirre, El catolicismo en presencia de sus disidentes, París, Librería de Garnier Hermanos, 1857, tomo II, p. 416.

75 "Construcción monumental", op. cit. 
Figura 3

Cesare Mariani, "Presentación de Jesús en el Templo" (Roma, 1870. Óleo sobre tela)

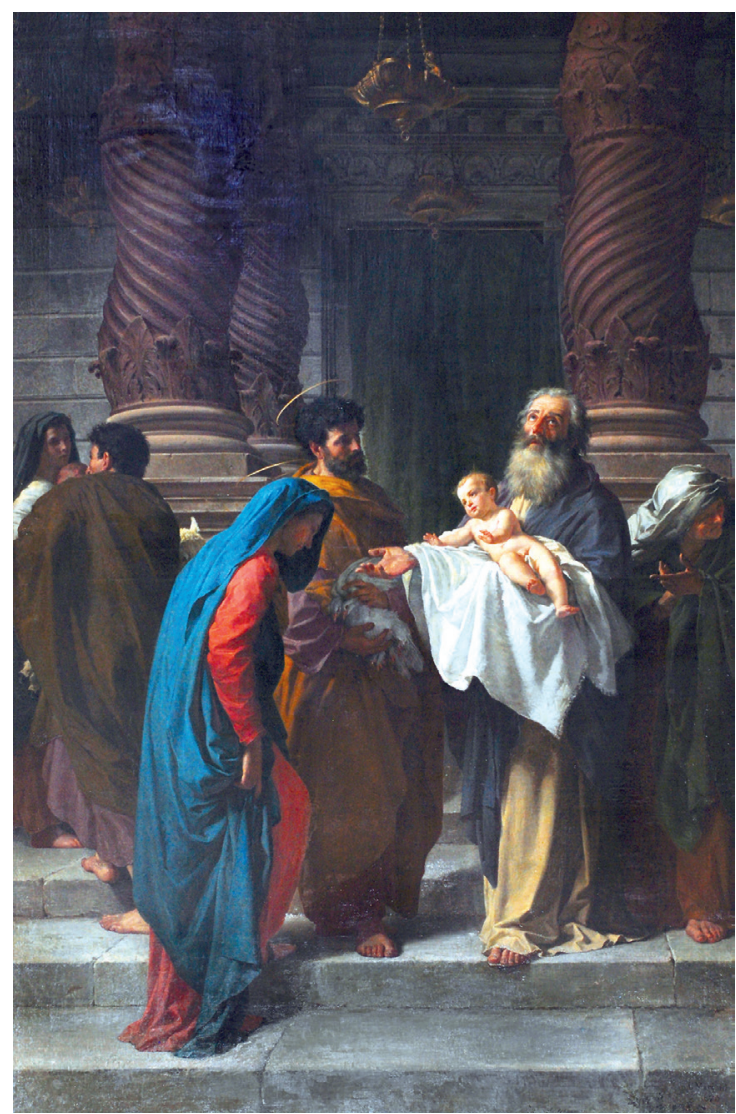

Fotografía: Giulio Archinà.

Las obras, destinadas a los altares laterales - que nunca llegaron a construirse-, fueron enviadas desde la Ciudad Eterna en julio de 1870. Antes de partir para el "lontano Chili", al menos una de estas pinturas fue expuesta en la "Esposizione Romana delle opere di ogni arte eseguite per il culto cattolico", y un periódico romano dio amplia noticia al respecto ${ }^{76}$. Se trata de un conjunto significativo en el que participaron: Casimiro Brugnone de Rossi, Enrico Bartolomei, Guido Guidi, Cesare Mariani, Pietro Pi, Roberto Bompiani, Alessandro Mencacci, Vincenzo Podesti, Giuseppe Sereni, Francesco Grandi y Francesco Coghetti ${ }^{77}$.

${ }^{76}$ Il Buonarroti, julio de 1870.

${ }^{77}$ No se cuenta con detalles sobre la comisión de esta serie de importantísimas telas. Por una carta de Francesco Coghetti a Giuseppe Carsana, del 30 de noviembre de 1869, se sabe que también debió estar involucrado el arquitecto Giovanni Montiroli, quien se había incorporado como académico de San Lucas. Capitelli, "Los 'pintores de Pio IX'...”, op. cit., p. 56, nota 57. 
Las obras y los artistas que en ellas trabajaron daban forma a un auténtico muestrario de la cultura artística romana del tercer cuarto del siglo $\mathrm{XIX}^{78}$.

Veintinueve años después del comienzo de las obras, con ocasión de la bendición del templo, la admiración parece no haber decaído. Un día antes de la ceremonia, el diario El Ferrocarril publica un extenso artículo con detalles de la arquitectura del templo y de las obras de arte albergadas en él; en el primer párrafo el redactor señala, con vehemencia, que el acontecimiento deberá "figurar en la historia de los progresos arquitectónicos realizados en la ciudad" 79 . Los santiaguinos, entusiasmados, desbordaron el templo los días $23,24,25$ y 26 de noviembre ${ }^{80}$; se puede suponer que la mayoría de ellos reparó en las principales características del edificio, sintetizadas por El Ferrocarril en tres conceptos: severidad, sencillez y buen gusto ${ }^{81}$. Sin duda, la Recoleta reunía todos los rasgos para ser un modelo de lo correcto, tanto desde el punto de vista artístico como del ambiente religioso que se buscaba promover ${ }^{82}$.

Desde su llegada a Chile, en 1853, hasta su muerte treinta y siete años después, Eusebio Chelli participó en obras de gran envergadura ${ }^{83}$. Trazó los planos y dirigió las obras de numerosos templos en Santiago: la Recoleta Dominica, San Ignacio, la Preciosa Sangre, el Buen Pastor, las Monjas Agustinas y los Capuchinos ${ }^{84}$. También tuvo a su cargo las obras de la parroquia del Sagrario, tarea en la que respetó el diseño definido por Joaquín Toesca en el siglo XVIII, y realizó algunas intervenciones en la catedral de Santiago. En arquitectura civil, su trabajo más relevante fue la construcción de una residencia para el abogado y político Maximiliano Errázuriz ${ }^{85}$, edificio que alberga en la actualidad a la Embajada de Brasil. También tuvo participación en la reconstrucción del Teatro Municipal de Santiago, de modo especial en aspectos ornamentales. Fuera de la capital, fue el arquitecto de la basílica menor de Andacollo y de la parroquia de Nuestra Señora de los Dolores en Viña del Mar, templo que fue demolido después del terremoto de $1906^{86}$.

\footnotetext{
${ }^{78}$ Capitelli, Mecenatismo pontificio..., op. cit., p. 118.

79 "Templo de la Dominica", en El Ferrocarril, n. ${ }^{\circ}$ 8556, Santiago, 23 de noviembre de 1882.

${ }^{80}$ El jueves 23 de noviembre monseñor Celestino del Frate, delegado apostólico, presidió la consagración de la iglesia.

81 "Templo de la Dominica", op. cit.

${ }^{82}$ Con ocasión del incendio de la iglesia de la Compañía en 1863, el templo barroco más importante de la ciudad, se desencadenó en la prensa un fuerte debate en torno al peligro que entrañaban los rebuscados retablos de madera y, en paralelo, una intensa crítica a una piedad que aludía solo al corazón y poco a la razón. Véase: Serrano, ¿Qué hacer..., op. cit., pp. 27-48.

${ }^{83}$ Para comprender el impacto que tuvo el trabajo de Eusebio Chelli en la ciudad de Santiago, véase: Juan Pablo Sepúlveda, "Eusebio Chelli, desafíos de una lectura histórica en Chile", en Fernando Pérez, Constructores y viajeros. La presencia de extranjeros en la construcción de la ciudad. Chile 1840-1940, Santiago, Pontificia Universidad Católica de Chile, Taller de Investigación de la Escuela de Arquitectura, 2001, pp. 1-33; Cristián Boza, Leonardo Castedo y Hernán Duval, Santiago, estilos y ornamentos, Santiago, Editorial Montt y Palumbo, 1983, pp. 22-23.

${ }^{84}$ Para obtener más antecedentes acerca de algunas de las iglesias levantadas por Eusebio Chelli, véanse: Fernando Pérez, Juan Benavides, Rodrigo Pérez de Arce y Mauricio Baros, 14 iglesias de Santiago de Chile, Santiago, Ediciones Universidad Católica de Chile, 2000; Campos, op. cit., p. 281; Capitelli, "Los 'pintores de Pio IX'...", op. cit.

${ }^{85}$ Sobre algunos rasgos arquitectónicos del palacio y antecedentes de sus propietarios, véase: Miguel Laborde, Santiago, lugares con historia, Santiago, Editorial Contrapunto, 1990, pp. 135-136.

${ }^{86}$ Sin duda Eusebio Chelli sostuvo una carga de trabajo importante mientras vivió en Chile, que se concentra en forma especial en los primeros nueve años. En 1872 abandona, por razones desconocidas, la mayoría de los trabajos que se encontraba realizando; por este motivo iglesias tan importantes como la Recoleta y San Ignacio debieron ser terminadas por otros arquitectos.
} 


\section{TIERRAS DE MISIÓN:}

\section{Nueva ARQuitectura para las viejas imÁGenes de Chiló́}

A los pocos años de que se pusiera la primera piedra de la iglesia de la Recoleta Dominica un cambio semejante comenzaba a operarse en el archipiélago de Chiloé, una de las zonas más periféricas del territorio chileno del siglo XIX. La falta de misioneros franciscanos en esta región obligó a reclutar frailes en Roma y Toscana para reforzar la atención religiosa ${ }^{87}$. Once de los dieciocho que desembarcaron en Valparaíso el año 1837 fueron destinados a las islas australes; uno de ellos, fray Diego Chuffa [Ciuffa], nombrado viceprefecto de misiones en la región, tuvo a su cargo la construcción de nuevas iglesias. Respetando la tradición local de arquitectura en madera, se hizo cargo de levantar un nuevo templo para la ciudad de Castro, que quedó terminado el año 1839. Algunos años después este edificio fue reemplazado por una obra más ambiciosa, también a cargo de fray Diego Chuffa [Ciuffa], que se levantó entre los años 1857 y $1859^{88}$ (Fig. 4).

Es probable que en esta obra haya colaborado otro franciscano, el toscano Leopoldo Scatulini, establecido en Chiloé desde el año 1857. A pesar de que esta iglesia no se conserva, las fotografías de su fachada permiten reconocer el clasicismo de su concepción. La obra destaca por la perfecta articulación y cuidadas proporciones del pórtico, frontón y torre, rasgos que evidencian el uso de planos. La fachada clasicista con torre central y pórtico, así como la concepción racionalizada y modular que facilitaba su reproducción en el territorio insular y continental se constituyó en una tipología nueva y moderna que definió el paisaje cultural de la evangelización.

Durante la segunda mitad del siglo XIX la mayoría de las decenas de iglesias del archipiélago fueron reedificadas tomando como patrón constructivo la iglesia de Castro, construida por el franciscano. En unas cuantas décadas desaparecieron casi todos los ejemplos de la arquitectura y la retablística barroca de los siglos XVII y XVIII (la única iglesia colonial que aún se conserva es la de Nuestra Señora de Loreto de Achao). Esta renovación de la arquitectura religiosa se explicaría, en gran medida, por la necesidad de reemplazar edificios precarios o que sufrieron daños por el embate de temporales, como está documentado para el caso de Chonchi.

Sin embargo, este proceso de reforma del espacio sagrado, de cuya recepción no se tiene registro, no fue acompañado por un cambio en las imágenes religiosas. Las iglesias neoclásicas de madera, con sus severos altares de pilastras acanaladas y frontones triangulares devinieron en hogar de las antiguas imágenes religiosas de factura local. Centenares de esculturas de madera policromada con vestidos de tela y cabelleras de pelo natural fueron albergadas en los nuevos edificios ${ }^{89}$. Las primitivas tallas de Chiloé,

\footnotetext{
${ }^{87}$ Jorge Pinto, “Jesuitas, franciscanos y capuchinos italianos en la Araucanía (1600-1900)", en Revista Complutense de Historia de América, n. ${ }^{\circ}$ 19, Madrid, 1993, pp. 109-147; Marciano Barrios, Presencia franciscana en Chile. Sinopsis histórica 1553-2003, Santiago, Orden Franciscana / Corporación Patrimonio Cultural de Chile, 2003, pp. 171-172.

${ }^{88}$ Lorenzo Berg y Gian Piero Cherubini, "El aporte de los misioneros franciscanos italianos en la tipología arquitectónica de la torre-fachada en las iglesias de Chiloé”, en AUS, n. ${ }^{\circ}$ 16, Valdivia, 2014, pp. 4-9.

${ }^{89}$ Fernando Guzmán, Lorenzo Berg y Rodrigo Moreno, "Las prácticas misionales y la articulación de espacio e imagen sagrada en el archipiélago de Chiloé, siglos XVII a XIX”, en Boletín Americanista, año LXX, 1, n. $^{\circ} 80$, Sevilla, 2020, pp. 103-125.
} 
ejecutadas a fines del siglo XVIII, convivían con el clasicismo de las edificaciones que emularon el modelo instalado por fray Diego Chuffa [Ciuffa].

\section{Figura 4}

Iglesia de San Francisco de Castro

(Diego Chuffa [Ciuffa], 1859)

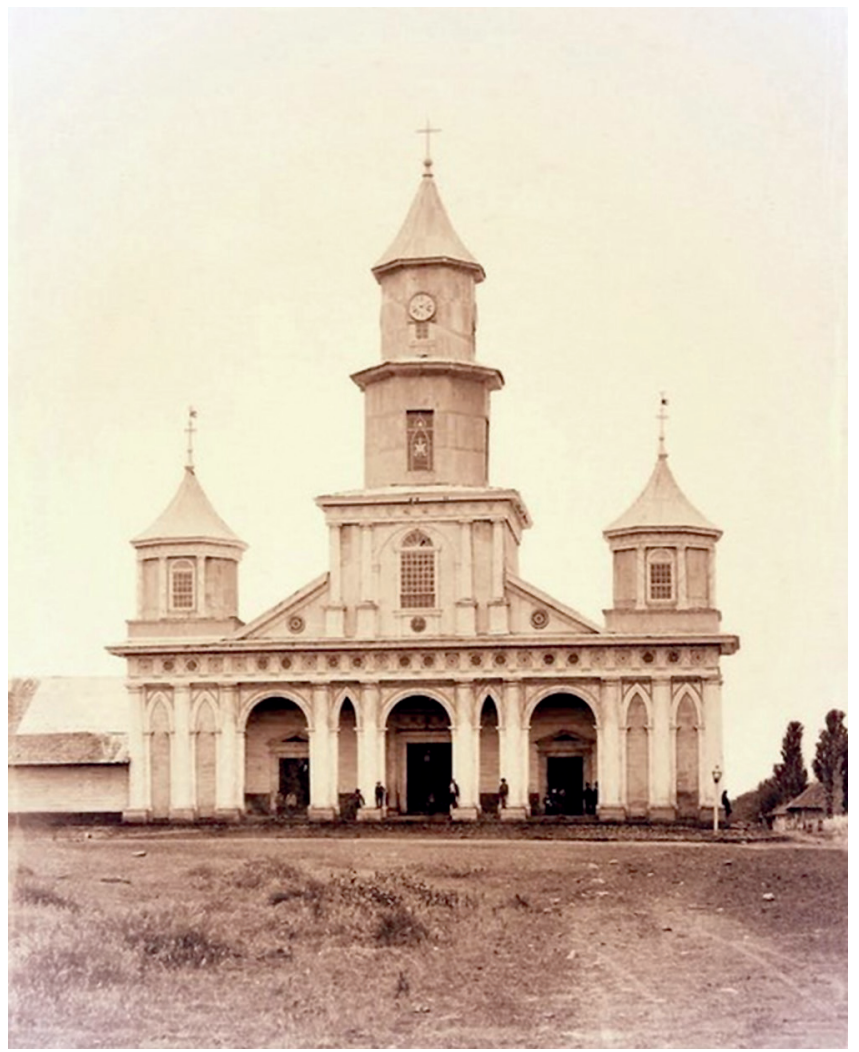

Fuente: Jermán Wiedenhold, 1893. Museo Municipal de Castro.

Debe tenerse en cuenta que la metodología de la misión circular, implementada por los jesuitas en Chiloé durante los siglos XVII y XVIII, consideraba el transporte de imágenes sagradas que se instalaban por unos pocos días en las desornamentadas capillas del archipiélago ${ }^{90}$. Los franciscanos de Ocopa, quienes asumieron la misión luego de la expulsión de la Compañía, acometieron de inmediato la adquisición de retablos, escul-

90 José García (1809-1811a). "Breve noticia de la misión andante por el Archipiélago de Chiloé, por el espacio de ocho meses", en Christoph Gottlieb von Murr (ed.), Nachrichten von verschiedenen Ländern des spanischen Amerika, Halle, Joh. Christian Hendel, vol. 2, pp. 600-615; en especial, pp. 600-602. 
turas y pinturas para las cerca de setenta capillas ${ }^{91}$. La dimensión de la empresa habría obligado a solicitar aportes a las familias de cada localidad, las que entregaron sus imágenes de devoción privada para ser ubicadas en los nuevos retablos. El reducido tamaño de muchas de las piezas presentes en la actualidad en las iglesias de Chiloé, la mayoría de ellas de factura local, así como la subsistencia de vínculos de propiedad respecto de ellas, son huellas de este paso de la devoción privada al culto público de muchas esculturas religiosas ${ }^{92}$. Se trata de un antecedente importante para calibrar el arraigo de las antiguas representaciones, con sus aderezos de cabello natural y ropajes de tela.

Por tanto, se puede afirmar que los suntuosos edificios de madera poseían una sacralidad que se supeditaba a la propia de imágenes religiosas de viejo cuño, a pesar de que como ya se indicó- el Sínodo de Ancud, celebrado el año 1851, señaló que las esculturas religiosas "no necesitan del adorno postizo de vestidos"93 y sus formas debían poseer una mínima dignidad. Las comunidades del archipiélago acogieron con entusiasmo la renovación arquitectónica, pero se habrían resistido a prescindir de sus viejas imágenes, las mismas que el catálogo de la Exposición del Coloniaje, celebrada en Santiago en 1873, calificaba como "un verdadero tipo chilote, del más horroroso estilo quiteño bizantino"

\section{NueVo CULTO, NUEVAS IMÁGENES: \\ La iglesia de San Ignacio de Santiago}

El año 1867, mientras en Chiloé se imponía el modelo arquitectónico clasicista de fray Diego Chuffa [Ciuffa], los jesuitas decidieron construir en Santiago una iglesia definitiva para el Colegio de San Ignacio, establecimiento que contaba solo con una pequeña capi1la. El edificio fue encargado a Eusebio Chelli, con la expresa intención de levantar algo que se asemejara en dignidad al nuevo templo de la Recoleta Dominica, pero que se debía construir en un tiempo reducido y con costos más bajos ${ }^{95}$. La restricción presupuestaria explicaría el hecho de que las columnas de mármol de la Recoleta fuesen reemplazadas por pilastras de mampostería de ladrillo, y que la madera fuese el material utilizado para levantar los altares y el púlpito. Los encargados de estos trabajos lignarios fueron los hermanos Rovira, hábiles en carpintería y en la pintura de falsos mármoles. Los altares, como se observa en la actualidad en el templo, corresponden a las tipologías de los que levantaron en Roma arquitectos como Virginio Vespignani, Luigi Poletti o Antonio Sarti96. De este modo,

91 "Manifiesto sobre la situación, estado y circunstancias notables de la provincia y archipiélago de Chiloé: y de lo que en ella han trabajado los religiosos Misioneros del Colegio de Propaganda Fide de Ocopa, en beneficio espiritual de aquellos fieles, desde que se les encargó su asistencia. Fray Pedro González de Agüeros, ex Guardián del expresado Colegio y su procurador en esta Corte", Madrid, 12 de agosto de 1788, en Archivo General de Indias, Audiencia de Chile, vol. 279.

${ }^{92}$ Guzmán, Berg y Moreno, op. cit., pp. 113-116.

${ }^{93}$ Retamal, op. cit., p. 126.

${ }^{94}$ Benjamín Vicuña Mackenna, Catálogo razonado de la Esposición del Coloniaje, celebrada en Santiago de Chile en setiembre de 1873. Por uno de los miembros de su Comisión Directiva, Santiago, Imprenta SudAmérica de Claro i Salinas, 1873.

95 “Consultas sobre la construcción de la Iglesia", en APCJ, 1867-1872.

${ }^{96}$ Gianfranco Spagnesi, L'archittetura a Roma al tempo di Pio IX 1830-1870, Roma, Studium, 2000, pp. 55-172. 
los jesuitas podían contar con un templo y unos altares que, a pesar de la ausencia de mármol, correspondían a los modelos arquitectónicos de la Ciudad Eterna (Fig. 5).

\section{FiguRA 5}

Altar lateral de San José, en la iglesia de San Ignacio (1872-1873)

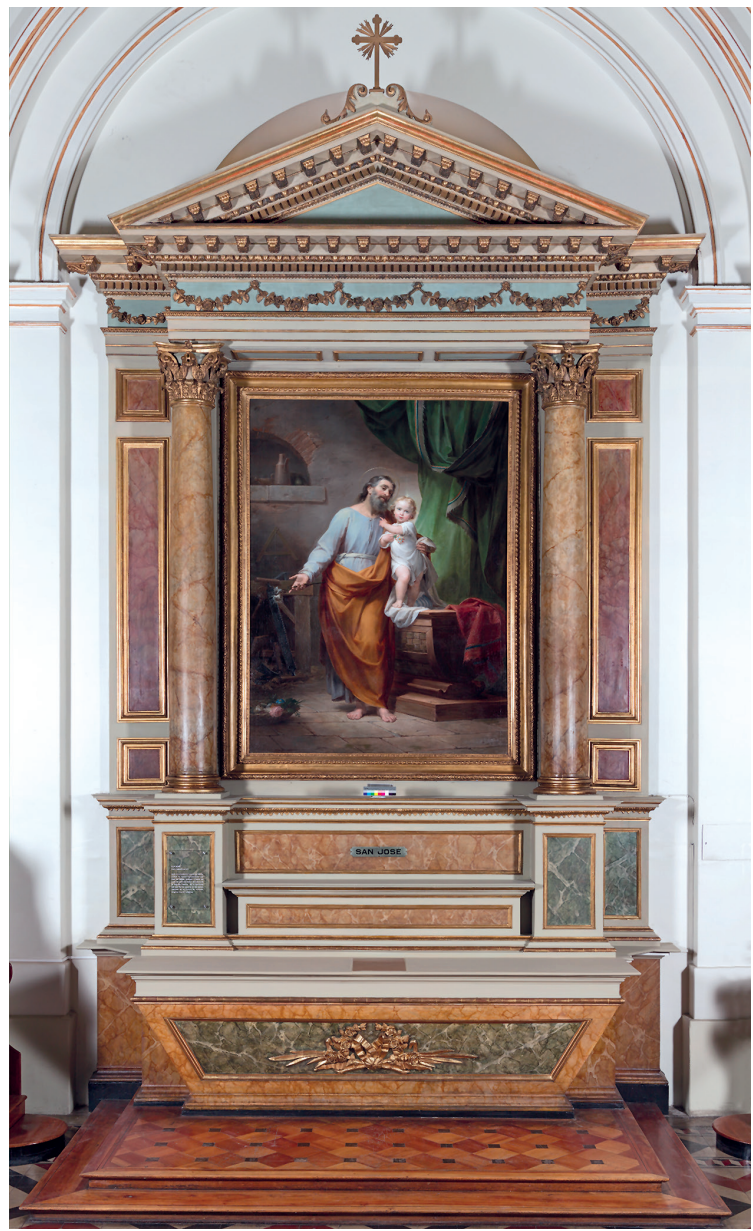

Fotografía: Centro de Restauración y Estudios Artísticos (CREA).

El recurso de los falsos mármoles es una clara manifestación de las dinámicas de adaptación de los modelos romanos a la realidad local ${ }^{97}$. Muchos artesanos de la zona

${ }^{97}$ La técnica del falso mármol o marmoridea -de importación jesuita en el caso de Chile, donde ellos la cultivaron desde fines del siglo XVII- era enseñada en el curso de la Accademia di San Luca. El oficio conoció en Italia un momento de gran desarrollo en el curso de la segunda mitad del siglo XIX, cuando fue promovida e industrializada por los nuevos ministerios de Pío IX, siendo usada también en la habilitación y 
central de Chile poseían una depurada técnica de imitación de mármoles ${ }^{98}$. Se trata de una tradición que instalaron en esta región coadjutores jesuitas hábiles en ebanistería y pintura desde comienzos del siglo XVIII ${ }^{99}$. Por otra parte, el uso de madera modificó de modo significativo los costos y complejidades de la obra, pues, como se indicó, el mármol debía ser importado desde Europa, con el consiguiente costo de transporte y el riesgo de pérdidas o graves deterioros. El contrato con los hermanos Rovira fue firmado en $1872^{100}$, el mismo año de consagración del templo, lo que permite pensar que a fines de ese año o a comienzos del siguiente los altares estaban instalados ${ }^{101}$. De este modo, la iglesia de San Ignacio fue la primera construcción eclesiástica de Santiago en mostrar el modelo romano de espacio y arte sacro, pues la iglesia de la Recoleta Dominica abriría sus puertas recién el año $1882^{102}$.

Unos meses antes de la consagración de la iglesia de San Ignacio, en septiembre de 1870, la comunidad jesuita discutía si era más conveniente adquirir pinturas o esculturas para los nuevos altares ${ }^{103}$. Uno de los padres opinaba "conviene más bien fuesen estatuas como son en Roma" 104 , testimoniando que el modelo arquitectónico y artístico de la Ciudad Eterna estaba presente de modo explícito en las reflexiones. A pesar de esta posición favorable a las esculturas, los retablos terminaron albergando pinturas, siete de ellas encargadas a algunos de los más prestigiosos artistas del círculo de Pío IX. A Pietro Gagliardi corresponden las telas de la Inmaculada Concepción, de Beata Margarita Alacoque adorando el Sagrado Corazón de Jesús, el San José con el Niño Jesús y el San Francisco Javier bendiciendo. El segundo artista que participa del encargo es Francesco Grandi, autor de la Visión de San Ignacio en Roma y San Francisco de Borja rezando delante del Santísimo. Para finalizar, se debe mencionar la Santísima Trinidad y Tetramorfos de Francesco Podesti (Fig. 6), uno de los pintores más relevantes del ambiente artístico romano del momento. De este modo, Roma se hacía presente no solo por medio de la concepción arquitectónica y el diseño de los retablos: siete pinturas excepcionales, ejecutadas por reconocidos artistas de la ciudad, dotaron al espacio sacro de su carácter definitivo ${ }^{105}$.

restauración de iglesias romanas. Elisabetta Pallottino, "Un'industria romana per le belle arti. Lo stabilimento della marmoridea a Villa Poniatowski (1855-1871)", in Roma moderna e contemporanea, n. ${ }^{\circ} 1-2$, Roma, 2000, pp. 229-244. En el sitio de la reconstrucción de San Pablo Extramuros se adoptaron otros sistemas para reemplazar el mármol monolítico, como los revestimientos de mármol pavonazzetto de las cuatro columnas del nuevo altar del ábside, que utilizaba, con complejas operaciones de corte, el mármol superviviente de las columnas de la antigua nave central. Elisabetta Pallottino, "Luigi Poletti, Prospetto dell'abside e della cattedra papale, 1837”, in Susinno, Pinto, Barroero y Mazzocca, op. cit., p. 494.

${ }^{98}$ Guzmán, Representaciones del paraíso..., op. cit., pp. 98-101.

${ }^{99}$ Op. cit., pp. 47-70.

100 "Contrato", en APCJ, 2/I/310, carpeta 03.

101 "Cuentas y recibos construcción iglesia", en APCJ, 2/J/308, carpeta 16.

${ }^{102}$ Fernando Guzmán, "La fortuna del modelo romano en las iglesias de Santiago. El caso de la iglesia de san Ignacio”, en Capitelli, Carroza, Cracolici, Guzmán y Martínez, op. cit., pp. 113-130, en particular pp. 118-129.

${ }^{103}$ Capitelli, Carroza, Cracolici, Guzmán y Martínez, op. cit.

104 "Consultas sobre la Construcción de la Iglesia", en APCJ, 2/J/300, carpeta 11.

105 Giovanna Capitelli, "Pietro Gagliardi (1809-1890) e il network internazionale della Compagnia del Gesù. Dipinti per Roma, Dublino, San Francisco, Santiago del Cile e Malta”, en Guzmán y Martínez, Vínculos artísticos..., op. cit., pp. 93-108; Giovanna Capitelli, "I Gesuiti e le arti nell'Ottocento. I 'pittori di Pio IX' nella chiesa di Sant’Ignazio a Santiago del Cile”, in Capitelli, Carroza, Cracolici, Guzmán y Martínez, op. cit., pp. 91-112. 
Figura 6

Franceso Podesti, "Santísima Trinidad y Tetramorfos"

(Roma, 1873. Óleo sobre tela)

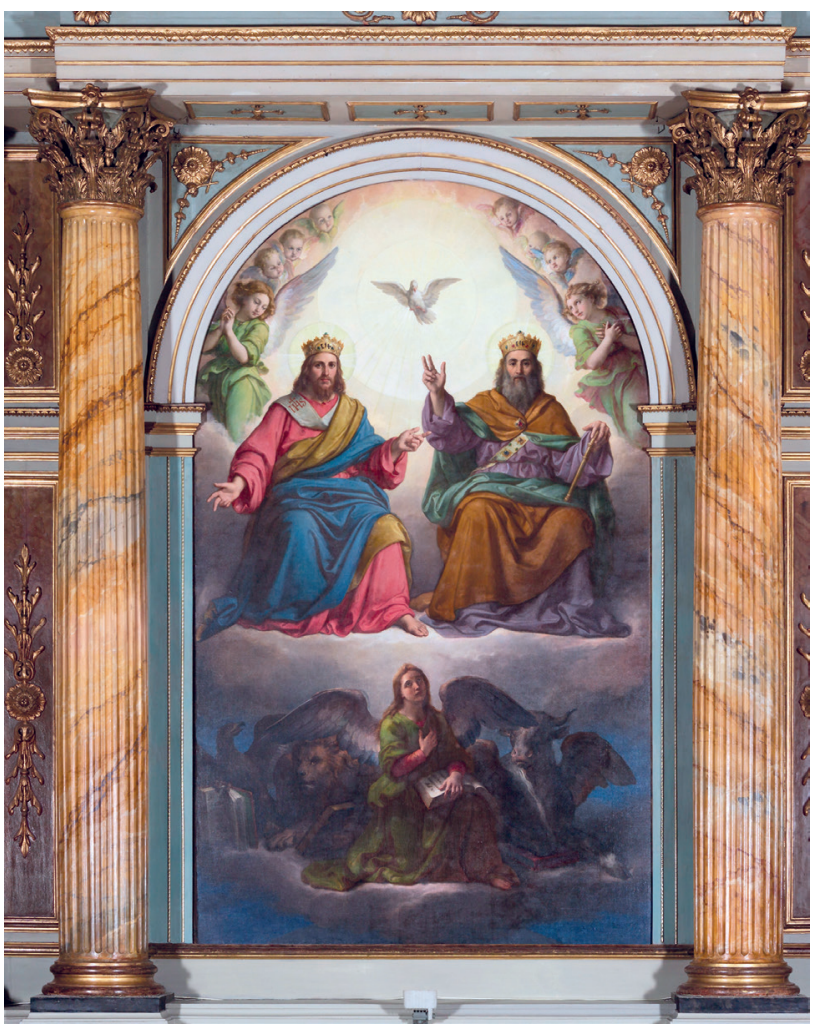

Fotografía: Centro de Restauración y Estudios Artísticos (CREA).

Los jesuitas hicieron una importante inversión en pintura italiana, solo comparable a la serie de los Misterios del Rosario en la Recoleta Dominica. La pintura de Francesco Grandi, representando a san Francisco de Borja, fue un obsequio de la familia Tocornal, mientras que por las otras tres obras debieron pagar más de catorce mil francos. Lo anterior se puede explicar por la mayor disponibilidad de recursos económicos de la Compañía, en comparación con los capuchinos o las religiosas del Buen Pastor, iglesias dirigidas por Eusebio Chelli que cuentan con programas artísticos más modestos. Sin embargo, también hay que tener en cuenta el deseo y necesidad de los jesuitas de manifestar su fidelidad a Roma, incluso en estos aspectos materiales ${ }^{106}$, así como su intención - como lo demuestran los documentos- de entregar a la ciudad de Santiago un modelo nuevo e integral de espacio e imagen sagrada.

${ }^{106}$ Es evidente la preferencia que el arzobispo Rafael Valentín Valdivieso sentía por los jesuitas; una de las razones era la posición antirregalista y antigalicana de la Compañía. Sin duda, contaba con ellos como aliados a la hora de defender la independencia de la Iglesia y la sujeción a Roma: Serrano, ¿Qué hacer.., op. cit., pp. 36 y 341. 


\section{La nUeVa iglesia de ANDACollo}

Y LA NECESIDAD DE EXTIRPAR PRÁCTICAS DE PIEDAD INAPROPIADAS

A los pocos meses de la consagración de la iglesia de San Ignacio de Santiago, en un pequeño poblado minero ubicado cuatrocientos kilómetros al norte de la capital se comenzó a levantar una de las iglesias más sorprendentes del siglo XIX. El monumental edificio sigue exhibiendo, a pesar de algunas transformaciones, una clara impronta romana. El pueblo de Andacollo alberga una de las fiestas religiosas más antiguas y masivas del norte chileno, a la vez que conserva el único edificio del arquitecto Eusebio Chelli levantado de forma íntegra en madera. Para entender el impulso que el obispo José Manuel Orrego le dio a la edificación de este templo es necesario considerar algunos antecedentes.

A los pocos meses de estar ejerciendo como ordinario de la diócesis de La Serena, monseñor José Manuel Orrego debió partir rumbo a Roma para participar en el Concilio Vaticano I. Los meses que pasó en la Ciudad Eterna le permitieron conocer los trabajos de arquitectura y arte religioso realizados durante el pontificado de Pío IX. Pudo asistir a la muestra de todas las artes para el culto católico, patrocinada por el Papa y dirigida por Virginio Vespignani en la Certosa di Santa Maria degli Angeli, visitar la recién restaurada basílica de San Pablo Extramuros, así como observar las esculturas y pinturas de las iglesias de la ciudad ${ }^{107}$. Si bien el viaje pudo suponer un retraso en diversos aspectos del gobierno eclesiástico, es plausible proponer que la observación de la arquitectura y el arte romano fueron insumos de gran valor para que el obispo José Manuel Orrego construyera un cierto modelo de espacio e imagen sagrada. Al volver a Chile pasó unos días por Santiago, circunstancia que debió aprovechar entre otras cosas para encargarle a Eusebio Chelli -arquitecto de la Recoleta Dominica y de la iglesia de San Ignacio de la capital- un diseño para levantar un nuevo templo en la localidad de Andacollo. No parece una mera coincidencia que nada más volver de Europa le haya encargado a Eusebio Chelli, quien había trabajado en la restauración de la basílica de San Pablo Extramuros, un proyecto o boceto para levantar un templo a la romana en una localidad conocida por sus coloridas manifestaciones de piedad popular, juzgadas quizá por el Obispo, si no como "absurdas, ridículas y detestables" 108 , al menos como inapropiadas.

La fiesta principal en honor a Nuestra Señora del Rosario de Andacollo se celebraba, al igual que en el presente, al día siguiente de la Navidad, atrayendo a numerosos peregrinos que se trasladaban a este pequeño asiento minero por algunas jornadas. Las danzas religiosas, así como el uso de disfraces y máscaras, eran rasgos distintivos de la fiesta $^{109}$. Se trataba de manifestaciones de piedad popular que eran vistas como ilegítimas desde la perspectiva de las autoridades eclesiásticas del siglo XIX. Si bien no se

${ }^{107}$ Sobre la muestra, véase: Giovanna Capitelli, “Il mercato globale dell'arte sacra nell'Ottocento. Pratiche, committenze, intermediari, artisti”, in Capitelli, Grandesso y Mazzarelli, op. cit., pp. 385-416.

${ }^{108}$ Orrego, op. cit., p. 73.

109 Juan Ramón Ramírez, "La Virjen de Andacollo: reseña histórica de todo lo que se relaciona con la milagrosa imajen que se venera en aquel pueblo", en El Correo del Sábado, La Serena, 1873, pp. 37-53; Rafael Contreras y Daniel González, Será hasta la vuelta de año, Santiago, Consejo Nacional de la Cultura y las Artes, 2014, pp. 79-103. 
conservan juicios explícitos del obispo José Orrego, su punto de vista acerca del culto público sería coherente con medidas que permitieran erradicar algunas de las prácticas que caracterizaban a la fiesta de Andacollo.

El 9 de diciembre de 1873 monseñor José Manuel Orrego firmó el decreto que ordenaba la construcción de una nueva iglesia en Andacollo "con arreglo a los planos levantados de nuestra orden por el Arquitecto don Eusebio Chelli", cuya primera piedra se colocó el 25 de diciembre del mismo año (Fig. 7).

\section{FiguRA 7}

Basílica de Nuestra Señora del Rosario de Andacollo (1873-1893)

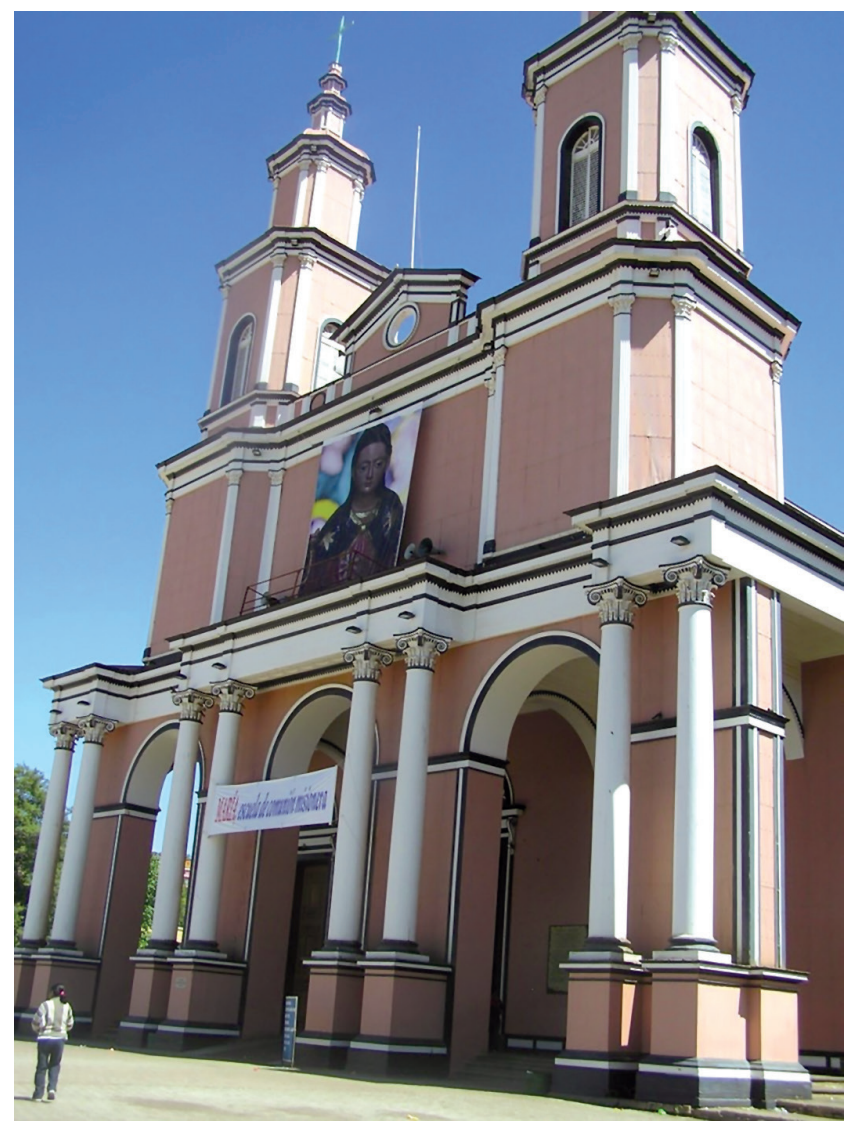

Fotografía: Fernando Guzmán.

El edificio, cuya construcción demoró veinte años, fue -y sigue siendo- el templo más grande de la región. Con una planta de setenta metros de largo por treinta de ancho y una torre que alcanza los cincuenta metros de altura, se impone como un coloso en el pequeño poblado. A pesar de que el obispo José Manuel Orrego no pudo ver el edificio 
terminado, se trató de su iniciativa edilicia de mayor envergadura. Resulta sorprendente que en el sitio que albergaba la principal fiesta religiosa popular de la diócesis se haya levantado un edificio de madera que recuerda a la basílica de San Pablo Extramuros, obra dirigida por Luigi Poletti, en la amplitud de su nave central y la composición de las torres, así como los pórticos de tres arcos que levantara el arquitecto Virginio Vespignani en el Cementerio de Verano y el Palacio de la Bolsa.

De esta manera, las heterodoxas expresiones de piedad en honor a la Virgen del Rosario comenzaron a convivir con el clasicismo de la iglesia diseñada por Eusebio Chelli de acuerdo con los modelos romanos que tan bien conocía. El nuevo edificio posee un sentido del orden coherente con un culto religioso sometido a las reglas litúrgicas, unas formas capaces de transmitir "una alta idea de la Majestad divina y hacer respetable su culto" ${ }^{110}$; características que parecieran contrastar con los bailes religiosos y las prácticas de piedad popular, ajenos a la normativa y el control eclesiástico.

\section{Los ecos de la Roma de Pío IX al término de la Centuria: La capilla del Seminario Pontificio de Santiago}

En las postrimerías del siglo XIX el arzobispo de Santiago, monseñor Mariano Casanova, impulsó dos proyectos de particular relevancia: la reforma de la catedral y la construcción de una nueva capilla doméstica para el Seminario de Santiago. En esta segunda obra es posible observar el carácter de la arquitectura de Ignazio Cremonesi, profesional romano que tuvo a su cargo ambos trabajos. El edificio de tres naves -la central, abovedada- fue bendecido por el Arzobispo el 14 de noviembre de $1898^{111}$. "El altar mayor, todo de mármol, con aplicaciones de bronce, ónix y lapislázuli"'112, debió ser diseñado por el mismo Ignazio Cremonesi, como se concluye de su coherencia con el conjunto edilicio.

Además de la arquitectura y el altar de mármol, el edificio contiene otros elementos que ponen de manifiesto su carácter romano. Se conserva aún una reliquia en cuerpo de cera de Julio Rústico Dulce, la que fue obsequiada por Pío IX al arzobispo Rafael Valentín Valdivieso en su primera visita ad limina ${ }^{113}$. Otra pieza destacable en este mismo sentido es la pintura de Carlo de Paris, realizada en Roma el año 1860 (Fig. 8). Se trata de un lienzo que "representa aquella escena bíblica en la cual habla Cristo de los Ángeles de esos niños que lo rodean"114.

\footnotetext{
${ }^{110}$ Orrego, op. cit., p. 78.

${ }^{111}$ Seminario Pontificio Mayor de Santiago de Chile, El Seminario Conciliar de los SS. Angeles Custodios en el quincuagésimo aniversario de la inauguración de sus actuales edificios. 1857-1907, Santiago, Imprenta de la Revista Católica, 1907, p. 62; Seminario Pontificio Mayor de Santiago de Chile, El Seminario de Santiago de los Santos Ángeles Custodios. Recuerdos, testimonio de veneración y gratitud de sus exalumnos, 1857-1957, Santiago, Imprenta Artes y Letras, 1958, vol. II, p. 918.

${ }^{112}$ Seminario Pontificio Mayor de Santiago de Chile, El Seminario de Santiago ..., op. cit., p. 920.

${ }^{113}$ Op. cit., pp. 920-992.

${ }^{114}$ Op. cit., p. 921.
} 
Figura 8

Carlo de Paris, "Sus ángeles ven el rostro del Padre"

(Roma, 1860. Óleo sobre tela)

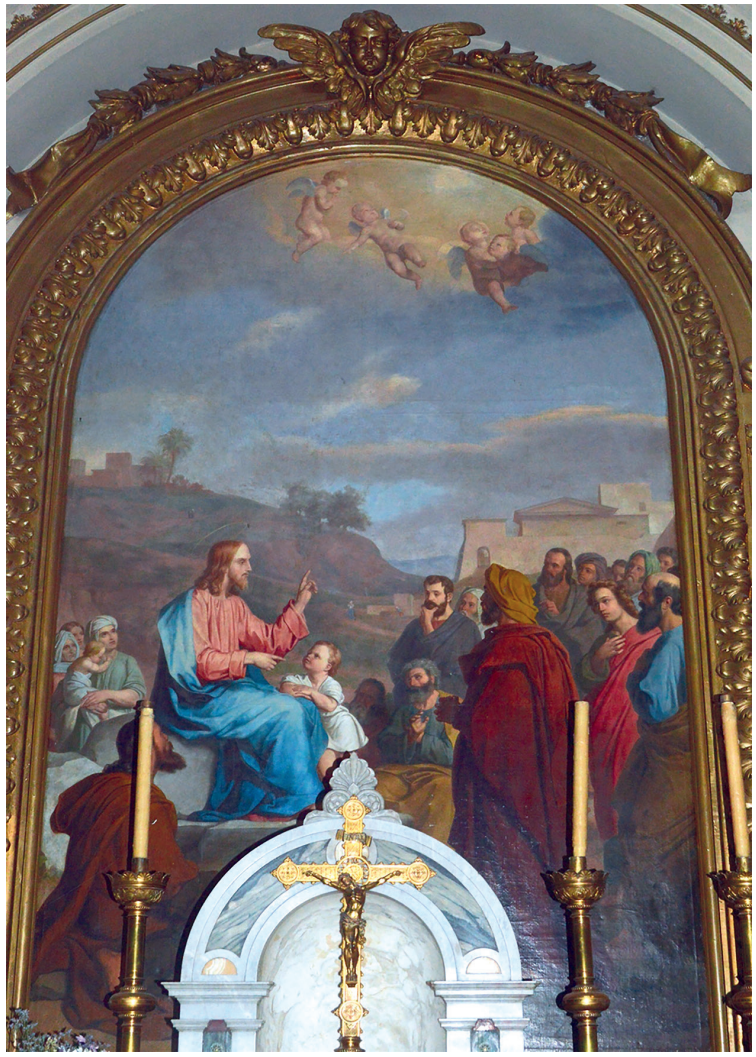

Fotografía: Claudio Díaz.

No solo se trata de un edificio construido por un arquitecto romano, en el que se alberga una pintura realizada en la Ciudad Eterna y una reliquia enviada por el Papa. Las fuentes consultadas dan cuenta de la relevancia de estos vínculos en el medio local. De Ignazio Cremonesi se señala que "vino especialmente desde Roma"115; de las reliquias del mártir se destaca que "fueron regaladas a monseñor Valdivieso por Pío IX"116; y de la obra de Carlo de Paris se recuerda que "es una pintura hecha en Roma"117. Si bien todas estas expresiones se contienen en un libro publicado medio siglo después de la construcción del templo, los textos están escritos por exalumnos que recuerdan en estas páginas lo que sus superiores o profesores comentarían acerca de la capilla.

\footnotetext{
${ }^{115}$ Seminario Pontificio Mayor de Santiago de Chile, El Seminario de Santiago..., op. cit., p. 917.

${ }_{116}$ Op. cit., p. 921.

${ }^{117}$ Ibid.
} 
Al trasladarse el Seminario a nuevas dependencias y demolerse los viejos edificios, la capilla de Ignazio Cremonesi fue conservada y erigida como parroquia de los Santos Ángeles Custodios. Su estructura y ornamentación interior no ha sufrido transformaciones significativas.

\section{CONCLusión}

Desde la llegada del altar de mármol para la Recoleta Dominica, en 1853, hasta la bendición de la capilla del Seminario de Santiago, en 1898, es posible seguir las huellas, en distintas zonas del territorio chileno, de las transformaciones del espacio y la imagen sacra a partir de modelos romanos. Al terminar el siglo XIX quedaban solo vestigios de la arquitectura y el arte religioso colonial: el trabajo de arquitectos como Eusebio Chelli, así como el arribo de tantas pinturas y esculturas desde Roma, habían colaborado de modo decisivo a borrar o desdibujar ese pasado que se consideraba pobre desde el punto de vista artístico y promotor de formas de piedad que debían ser erradicadas.

La construcción de la nueva iglesia de Andacollo es el ejemplo más claro de esta voluntad de transformar el comportamiento de los fieles mediante la renovación de la arquitectura. La convicción del obispo José Manuel Orrego acerca de la necesidad de purificar el culto público de expresiones desviadas y su empeño por construir en la pequeña localidad de Andacollo, epicentro de las más llamativas prácticas religiosas sincréticas, una monumental iglesia diseñada por Eusebio Chelli, manifiestan el espíritu de lo que ocurrió durante la segunda mitad del siglo XIX. Sin embargo, este caso y el de Chiloé ponen de manifiesto que, en determinadas circunstancias, la población local resiste de manera efectiva estos procesos de reforma. Por una parte, las prácticas devocionales características de la festividad de Nuestra Señora de Andacollo mantuvieron su vitalidad a pesar de la construcción del nuevo templo. Por otra, el modelo de iglesia clasicista que impuso fray Diego Chuffa [Ciuffa] en el archipiélago de Chiloé no provocó una transformación de la imagen sagrada; por el contrario, los nuevos retablos comenzaron a albergar las viejas esculturas de talla local, vestidas y policromadas.

Distinto es lo que ocurre con las iglesias levantadas en Santiago, en las que se pueden observar tres rasgos relevantes. En primer lugar, se trata de obras en que arquitectura e imágenes son coherentes; segundo, hay una reacción entusiasta de la opinión pública y, para finalizar, los nuevos templos se constituyen en modelos replicables. Las dos primeras características se manifiestan con contundencia en la nueva iglesia del convento de la Recoleta Dominica, pues se trata de un edificio entroncado en forma directa con la arquitectura romana del siglo XIX y adornado con lienzos pintados por artistas que formaban parte del círculo más estrecho del papa Pío IX, circunstancias que le valieron una cobertura de prensa como pocas obras edilicias de la ciudad recibieron. La iglesia de San Ignacio, por su parte, adapta los modelos romanos a los requerimientos locales, dando forma a una solución más económica y ejecutada con materiales locales, peculiaridades que la convirtieron en un referente accesible a la hora de concebir nuevos templos o al planificar la renovación de un edificio antiguo.

Muchos otros casos deben ser analizados para tener una visión completa de lo que ocurrió durante la segunda mitad del siglo XIX; las transformaciones de la catedral de 
Santiago, el adorno de la nueva catedral de Concepción, así como numerosos templos que se renovaron o construyeron deben ser incorporados al análisis. Los ejemplos presentados permiten suponer una mayor iniciativa del clero regular, favorecidos por su mayor autonomía para tomar decisiones. Sin embargo, la construcción de la basílica de Andacollo y de la capilla del Seminario Pontificio de Santiago son manifestaciones del empeño de los obispos por impulsar cambios en la configuración de la arquitectura religiosa. En Chile se llevó adelante un proceso a gran escala de transformación del espacio y la imagen sagrada, impulsado entre otros por fray Juan O'Brien, monseñor José Ignacio Víctor Eyzaguirre y los obispos José Manuel Orrego y Justo Donoso. Proceso que no solo contó con la participación de arquitectos, pintores y escultores de formación romana, sino que envolvió la apropiación del prestigio multidimensional de la Ciudad Eterna. 